\title{
21. YÜZYILDA EVRENSEL BİR YARGI KURULUŞU OLARAK ULUSLARARASI CEZA MAHKEMESİ: USUL KURALLARI, YARGILAMALAR VE ULUSLARARASI SUÇLAR
}

\author{
Arda ÖZKAN ${ }^{1}$
}

Özet: Uluslararası Ceza Mahkemesi, soykırım suçları, insanlığa karşı suçlar, savaş suçları ve saldırı suçları gibi uluslararası toplum tarafından kınanmış en ciddi uluslararası suçları işleyen bireyleri yargılamak için kurulmuş uluslararası bir yargı kuruluşudur. Uluslararası Ceza Mahkemesi'nin kuruluş amacı, uluslararası suçlarla mücadelede uluslararası düzeyde örnek bir adalet sağlamak, bu tür suç mağdurlarının zararını gidermek, uluslararası düzeyde sosyal değerleri ve bireysel dürüstlüğü güçlendirmek, uluslararası suçlar konusunda günümüz nesillerini eğitmek ve en önemlisi de gelecekte muhtemel bu tür insani çöküşleri önlemek ve cezasız kalmayacağı inancını yerleştirerek insanları vazgeçirmektir. Uluslararası Ceza Mahkemesi'nin kuruluşu, hukukun üstünlüğü ve insan haklarının gelişimi yönünde atılmış önemli bir adım ve gelecek nesillere bir ümit kaynağı olarak değerlendirilmektedir. $\mathrm{Bu}$ çalışmada, Uluslararası Ceza Mahkemesi'nin yargı yetkisi içerisine giren soykırım suçları, insanlığa karşı suçlar, savaş suçları ve saldırı suçlarını işleyen bireylerin cezai sorumluluğu genel olarak uluslararası hukuk, özel olarak da uluslararası ceza hukuku açısından incelenmiştir.

Anahtar Kelimeler: Soykırım, insanlığa karşı suçlar, savaş suçları, saldırı suçu, bireysel cezai sorumluluk.

Jel Kodu: K14, K33.

\section{THE INTERNATIONAL CRIMINAL COURT AS A UNIVERSAL JUDICIAL INSTITUTION IN THE $21^{\text {ST }}$ CENTURY: RULES OF PROCEDURE, JUDGEMENTS AND INTERNATIONAL CRIMES}

\begin{abstract}
The International Criminal Court is a judicial organization founded to judge the persons who committed in genocide, crimes against humanity, war crimes, and crimes of agression which have been disapproved by international society as the most crucial crimes. The objective of the International Criminal Court is securing a model justice at international level in fighting against crimes, compensating victims of such crimes, empowering social values and individual honesty at international level, educating youth of today in international crimes, and the most important preventing such possible humanistic falls in future, and settling the belief that the crimes are not to remain unpenalized, so discouraging persons. Foundation of the International Criminal Court is seen as a significant step in development of human rights and rule of law, and a source of hope for future generations. In this study, criminal responsibility of people committed in genocide crimes, crimes against humanity, war crimes and crimes of agression in the jurisdiction of the International Criminal Court have been studied from the general point of international law, and especially from the point of international criminal law.
\end{abstract}

Keywords: Genocide, crimes against humanity, war crimes, crime of aggression, individual criminal responsibility.

Jel Code: K14, K33.

\footnotetext{
1 Arş. Gör., Giresun Üniversitesi, İktisadi ve İdari Bilimler Fakültesi, Uluslararası İlişkiler Bölümü (ardaozkan83@hotmail.com).
} 


\section{Giriş}

21. yüzyılın globalleşen dünyasında her geçen gün insanlığa ve insan hayatına verilen değer artarken, teknolojinin ve insan hırslarının bir yansıması biçiminde insanlığa karşı tehlikeler de korkunç boyutlara ulaşmıştır. Ulusal mahkemeler, savaş suçları ve soykırım gibi uluslararası nitelikteki suçları yargılama yetkisine sahip olmalarına rağmen, devlet içindeki mevcut olan siyasi çıkar oyunları buna izin vermemiştir. Öte yandan, insan haklarının eylemsel korunması çerçevesinde, devletin sorumlu tutulmasının yetersizliği, devlet kadrolarında görev alan kişilerin de sorumlu tutulmasını zorunlu kılmıştır (Çınar, 2004: 1).

Uluslararası hukukta devletlerin sorumluluğu yanında, bireylerin cezai olarak sorumlu tutulabilmeleri ve işlemiş oldukları uluslararası suçlardan dolayı ulusal ya da uluslararası mahkemeler aracılığıyla cezalandırılmalarının sağlanması uluslararası ceza hukukunun en temel amaçlarından biri olmakla beraber, bireylerin sorumluluğu konusunun uluslararası alanda uygulanması oldukça yenidir (Aksar, 2003: 18). Devletlerin kendi vatandaşlarını uluslararası suç sebebiyle ulusal mahkemelerde yargılamak istememesi nedeniyle uluslararası nitelikli ceza kuruluşlarının kurulması kaçınılmaz olmuştur (Aksar, 2005: 2).

Gerçek kişilerin uluslararası hukuka kapsamlı bir biçimde konu oluşturmaları, İkinci Dünya Savaşı'nı takiben insan hakları bağlamında olmuştur. Çok sayıda evrensel veya bölgesel nitelikli antlaşma çerçevesinde, bir yandan kişilerin sahip oldukları haklar ayrıntılı bir biçimde düzenlenirken, diğer yandan da bu hakların korunması amacıyla kişilerin başvurusuna da açık bir takım koruma mekanizmaları geliştirilmiştir (Ekşi, 2004: 1). Bu mekanizmalardan birisi, evrensel bir yarg1 kuruluşu olarak kurulan Uluslararası Ceza Mahkemesi'dir. Haziran-Temmuz 1998 tarihlerinde, uluslararası suçları işleyen kişilerin yargılanmaları için Roma'da Uluslararası Ceza Mahkemesi Statüsü’nün oluşturulması ile ilgili bir Birleşmiş Milletler Konferansı düzenlenmiş ve bu konferans sonucunda imzaya açılan Roma Statüsü'nün 5. maddesinde Mahkeme'nin uluslararası suçları yargılama yetkisine sahip olduğu belirlenmiştir.

Uluslararası Ceza Mahkemesi, 17 Temmuz 1998'de kabul edilen Roma Statüsü ile kurulmasının ve 60. onay belgesinin teslim edilmesinin ardından 1 Temmuz 2002 tarihinden itibaren de çalışmalarına başlamıştır. Uluslararası Ceza Mahkemesi; soykırım² ${ }^{2}$, insanlığa karşı suçlar ${ }^{3}$, savaș suçları ${ }^{4}$ ve saldırı suçları ${ }^{5}$ gibi uluslararası toplum tarafından kınanmış en ciddi uluslararası suçları işleyen bireyleri yargılamak için kurulmuş uluslararası bir yargı kuruluşudur. Söz konusu uluslararası suçların Mahkeme'nin yargı yetkisine dahil edilmesiyle, insanlık tarihine geçmiş karanlık sayfaların tekrarlanmaması, tekrarlandığı takdirde sorumluların cezalandırılabilmesi amaçlanmıştır (Uzun, 2003: 26).

Uluslararası Ceza Mahkemesi’nin yargı yetkisine dahil edilen suçlar, antlaşmalar hukuku, uluslararası teamül hukuku, uluslararası hukukun emredici kuralları (jus cogens) ve insan

\footnotetext{
${ }^{2}$ Soykırım suçu üzerinde Uluslararası Ceza Mahkemesi’nin yargı yetkisinin olduğu, Mahkeme Statüsünün 5. maddesinde belirtilmiş olup, hangi suçların bu kategoriye dahil olduğu ve suçun unsurlarının neler olduğu ise Statünün 6. maddesinde 1948 tarihli Soykırım Sözleşmesi’nden alıntı yapılarak düzenlenmiştir.

${ }^{3}$ İnsanlığa karşı suçlar üzerinde Uluslararası Ceza Mahkemesi’nin yargı yetkisinin olduğu, Mahkeme Statüsünün 5. maddesinde ifade edilmiş ve bu kategoriye dahil edilen suçların nelerden oluştuğu Statünün 7. maddesinde düzenlenmiștir.

${ }^{4}$ Uluslararası Ceza Mahkemesi Statüsü'nün 5. maddesi, Mahkeme'nin savaş suçları hakkında yargı yetkisine sahip olduğunu hükme bağlarken, bu gruba giren suçların kapsamını detaylı bir şekilde Statü’nün 8. maddesinde düzenlemiștir.

${ }^{5}$ Uluslararası Ceza Mahkemesi Statüsü 5. maddesinde, saldırı suçları hakkında Mahkeme'nin yargı yetkisi olduğu ifade edilmiştir. Ancak bu suçun tanımının Mahkeme Statüsü'nde yapılmadığı görülmektedir. 2010 yılında gerçekleştirilen Gözden Geçirme Konferansı'nda Roma Statüsü’de yapılan değişiklikle netleşmesinden sonra ancak Mahkeme’nin saldırı suçlarından dolayı bireyleri yargılayabilmesi söz konusu olmuştur.
} 
hakları hukukunun bir birleşimi olarak, 20. yüzyıl boyunca gelişen ve genel kabul gören, uluslararası ceza hukuku prensiplerinin birer yansımasıdır. Bütün bu uluslararası hukuk kuralları, kaynağını devletlerin egemenlik ilkelerinden almakta ve yine devletlerin rızalarına dayanmaktadır (Çınar, 2004: 46).

Uluslararası Ceza Mahkemesi, insancıl hukuk kapsamındaki kimi suçları kovuşturan ve 20. yüzyılın sonlarında kurulup, 21. yüzyılda uluslararası insancıl hukukun egemenliğine katk1 yapan ilk uluslararası mekanizmadır. Bu haliyle en ağır suçların faillerinin cezasız bırakılmaması yönünde büyük bir adımı temsil eden ve kuruluşundan bu yana yaklaşık 120 ülkenin yargı yetkisini tanıdığı mahkeme, insan hakları hukuku açısından da yeni bir döneme işaret etmektedir. Roma Statüsü'nde Mahkemenin yargı yetkisine giren soykırım, insanlığa karşı suçlar, savaş suçları ve saldırı suçunun yeryüzünde işlenmiş en ciddi suçlar olduğu ve bu suçların gerçekte dünyanın barış ve güvenliği tehdit eden eylemler olduğu ifade edilmiştir.

\section{Tarihçe}

1919 yılında Birinci Dünya Savaşı'nın sonunda imzalanan Versay Antlaşması'nda, savaş suçlularını yargılamak üzere, savaşın galipleri olan ABD, Fransa, İngiltere, İtalya ve Japonya'dan seçilen yargıçlardan oluşan özel bir mahkeme kurulması öngörülmüştü (Köprülü, 2005: 44). ${ }^{6} \mathrm{Bu}$ antlaşmada başta Kayser II. Wilhem olmak üzere savaş ve yasa geleneklerini ihlal eder biçimde suç işleyenlerin kurulacak özel bir mahkemede yargılanmaları öngörülüyordu (Ekşi, 2004: 3). Fakat savaş sonunda II. Wilhem'in Hollanda'ya sığınması ve Hollanda'nın Kayser'in yargılanması için iade etmemesi üzerine, hakimlerinin bile hangi uluslardan olacağı belirlenmiş bu uluslararası ceza mahkemesi hayata geçirilememiş (Çınar, 2004: 10) ve Versailles Antlaşması ile kurulması öngörülen bir ceza mahkemesi hiçbir zaman kurulamamıştı. Birtakım politik engellemeler de, böyle bir mahkemenin faaliyete geçebilmesi için siyasi iradenin oluşumunu baltalamıştı. Sonuç olarak, adalet bir kez daha siyasete yenilmiş (Önok, 2003: 32) ve uluslararası ceza hukukunda ilk sayılabilecek bir girişism başlamadan sona ermiştir.

İkinci Dünya Savaşı, uluslararası bir ceza mahkemesi kurulması fikrinin yeniden canlanmasına neden olmuştur. Savaşı takiben müttefik devletler tarafindan itilaf devletlerinin hizmetindeki savaş suçlularını yargılamak üzere oluşturulan Nuremberg ve Tokyo Uluslararası Ceza Mahkemeleri, bu canlanmanın somut göstergeleri olmuşlardır (Ekşi, 2004: 4).

8 Ağustos 1945 'te kurulan Nuremberg Uluslararası Ceza Mahkemesi, uluslararası hukukun o döneme kadar meşru saydığı kuvvet kullanma eylemleri ve sınırlandırılmasıyla ilgili olarak, uyulması gereken kuralların ihlali sonucunu ortaya çıkarmış olmakla birlikte, uluslararası suçların yargılanmasıyla ilgili ilk mahkeme olma özelliğini taşımaktadır. Nuremberg Mahkemesi Statüsü'nün yargı yetkisine giren suçlar ana hatları ile barışa karşı suçlar, savaş suçları ve insanlığa karşı suçlar olmak üzere üç grup altında tanımlanmıştır. Mahkeme Statüsü'nde belirtilen ihlaller ise; gereksiz yoksunluğa neden olan zehirli silahların ve diğer silahların kullanımı; askeri bir zorunluluk olmaksızın kent, kasaba ve köylerin geniş ölçüde tahrip edilmesi; savunmasız kasaba, köy, bina ve evlerin her türlü araçlarla bombalanması ve saldırıya uğraması; dinsel, eğitsel, sanatsal, bilimsel ve tarihsel mekanların kasitlı olarak büyük ölçüde tahrip edilmesi; kamu ve özel mülkiyetin yağmalanmasıdır. Bu eylemlerin gerçekleştirilmesi, savaş hukuku ve teamüllerin ihlali sayılmıştır (Azarkan, 2003: 64). Belirtilen suçların "jus ad bellum", ve "jus in bello", kapsamında örf-adet niteliği kazanmış

\footnotetext{
${ }^{6}$ Bu kapsamda Birinci Dünya Savaşı'nın hemen arkasından 1919 yılında imzalanan Versailles Antlaşması, uluslararası ceza mahkemelerinin kuruluşunda milat olacak bir öneme sahiptir.

${ }^{7}$ Kuvvete başvurmayı düzenleyen hukuk.

${ }^{8}$ Kuvvet kullanılması sırasındaki eylemleri düzenleyen hukuk.
} 
kuralların ihlallerinden oluştuğu Mahkeme tarafından kabul edilmiş ve yargılamalar bu temelde yapılmıştır. Nuremberg Mahkemesi, aslında Anglo-Amerikan ve Kıta Avrupası Hukuku'nun ortak bir yansımasıdır (Kurşun, 2011: 31). ${ }^{9}$ Genel olarak bakıldığında uluslararası mahkeme gibi görünen bu mahkeme aslında yerel hukuka tabi bir ad hoc mahkeme niteliği taşımaktadır. Nuremberg Mahkemesi, daimi bir uluslararası ceza mahkemesi kurma yönündeki çabalar açısından tam anlamıyla dönüm noktası olmuştur. Aynı zamanda Mahkeme ile savaş suçlarında bireysel sorumluluk kavramı kabul edilmiştir. Böylece, yalnız devletlerin değil, bireylerin de uluslararası hukuka uymak zorunda oldukları ortaya çıkmıştır.

İkinci Dünya Savaşı'nın hemen sonrasında kurulan diğer bir ad hoc mahkeme de Tokyo Uluslararası Askeri Ceza Mahkemesi'dir. Bu mahkemenin yarg1 yetkisi, Japonya ve Pasifik'te Amerikan Ordusu Başkomutanı idaresi altında bulunan bölgeleri kapsamış ve sadece savaş suçları değil, insanlığa ve barışa karşı suçları da içerecek şekilde kurulmuştur (Başak, 2003: 32). ${ }^{10}$ Tokyo Mahkemesi'nin yarg1 yetkisine giren suçlar, Nuremberg Mahkemesi Statüsü'nde olduğu gibi üç maddedir: Barışa karşı suçlar, konvansiyonel savaş suçları ve insanlığa karşı suçlardır. Suçlardan barışa karşı suçlar ile insanlığa karşı suçlar, Nuremberg Statüsü'ndekine benzer bir içeriğe sahipken, konvansiyonel savaş suçu daha belirsiz ve genel bir ifade ile kaleme alınmıştır (Çınar, 2004: 16).

Bu davalarda o dönemki Nazi Almanyasıyla Japonya'nın çeşitli pozisyonlarda görev yapan asker ve sivil devlet yöneticileri yargılanmış, idam cezasına varan cezalar verilmiştir. Ne var ki, bu yargılamalarda, galipler mağlupları yargıladıkları için ne kadar adil davranıldığı ya da yargılamaların sınırlı tutuluşu bugüne kadar hep eleştirilmiştir. İkinci Dünya Savaşından sonra yapılan yargılamalardan bu yana yarım yüzyılı aşkın bir süredir, devletler soykırım suçunun, insanlığa karşı suçların ve savaş suçlarının milyonlarca kurbanı adına bu suçların sorumlularını adalet önüne getirme konusunda çoğunlukla başarısız olmuşlardır (Schabas, 2000, 32).

Nuremberg ve Tokyo Mahkemeleri'ni izleyen süreçte gelişen iki önemli sözleşme, uluslararası ceza mahkemelerinin oluşum tarihinde, üzerinde durulması gereken önemli hususlar olarak göze çarpmaktadır. Bunlardan ilkini 12 Eylül 1948'de Birleşmiş Milletler Genel Kurulu'nun kabul ettiği “Soykırım Suçunun Önlenmesine ve Cezalandırılmasına Dair Antlaşma (Soykırım Sözleşmesi)" oluşturmaktadır. Bu antlaşma ile uluslararası toplum açısından soykırım suçu gibi uluslararası suçların önlenmesi ve yargılanması gerekliliği kabul edilmiştir. İkincisini 12 Ağustos 1949'da kabul edilen ve dört parçadan oluşan 'Cenevre Sözleşmeleri” oluşturmaktadır. Soğuk Savaş dönemine genel olarak bakıldığında, uluslararası ceza yargılaması konusunda bazı fikirler üretilmiş, ancak bunların hiçbirisi kesin bir destek bulamamıştır.

Soğuk Savaş’ın ardından 1993-1994 yıllarında kurulan Yugoslavya ve Ruanda Ceza Mahkemeleri, Birleşmiş Milletler tarafından uluslararası kamuoyu adına faaliyet göstermek üzere tesis edilmiştir. Birleşmiş Milletler Güvenlik Konseyi'nin, Eski Yugoslavya ve Ruanda'daki insan hakları ve uluslararası ceza hukuku ihlalleri karşısında, Birleşmiş Milletler

\footnotetext{
${ }^{9}$ Dünyada dört büyük hukuk sistemi bulunmaktadır. Bunlar Kıta Avrupası Hukuk Sistemi, Anglo-Amerikan Hukuk Sistemi, İslam Hukuk Sistemi ve Sosyalist Hukuk Sistemidir. Roma Statüsü, bir BM belgesi olarak uzlaşma ürünüdür, dolayısıyla tüm bu hukuk sistemlerinden bazı izler taşır. Karma olarak, dünyadaki tüm hukuklardan izler taşıyan bu hukuk metni, en iyi yönlerini toplayarak dört hukuk sisteminin de kimi yönlerini yansıtır. İki hukuk sisteminin, Anglo-Amerikan Hukuk Sistemi ile Kıta Avrupası Hukuk Sisteminin diğerlerine oranla biraz daha baskın biçimde Statüye yansıdığı düșünülmektedir.

${ }^{10}$ Ancak belirtilmesi gerekir ki, Japonya'ya atom bombası atılması başta olmak üzere yoğun bombardımanın neden olduğu sivil kayıplar, uluslararası insancıl hukuk ihlalleri olmasına rağmen, yargılama konusu bile teşkil etmemiştir.
} 
Antlaşması'nın VII. Bölümü çerçevesinde uluslararası barış ve güvenliğin korunması için kurulan uluslararası savaş suçluları mahkemelerinin düzenleme ve uygulamalarına Nuremberg ve Tokyo Mahkemeleri örnek teşkil etmiştir (Aksar, 2005a: 3). Hem Nuremberg hem de Tokyo Uluslararası Ceza Mahkemesi, statüleri ve yetkileriyle, kurulması düşünülen daimi uluslararası ceza mahkemesinin kurulmasına ön ayak olmuşlar; ayrıca yargılama ve diğer faaliyetleriyle bir daimi mahkeme açısından örnek ve referans teşkil etmişlerdir (Önok, 2003: 55; Aksar, 2005a: 3). ${ }^{11}$

1993 yılında Avrupanın ortasında Eski Yugoslavya topraklarında yaşanan vahşete kayıtsız kalamayan uluslararası toplum, BM müdahalesi sonrasında Eski Yugoslavya topraklarında işlenen suçların yargılanabilmesi için geçici (ad hoc) nitelikte bir uluslararası ceza mahkemesi kurulmasına karar vermiștir. 1993 yılında, BM Güvenlik Konseyi, uluslararası toplum adına aldığı 808 sayılı kararda, 1991 yılından beri Eski Yugoslavya sınırları içinde meydana gelen ağır insan hakları ihlallerinden sorumlu kişileri yargılamak amacıyla bir uluslararası mahkemenin kurulmasını ve bu çerçevede aldığ 827 sayılı kararla da uluslararası mahkemenin statüsünü kabul etmiştir (Azarkan, 2003: 126). Eski Yugoslavya Uluslararas1 Ceza Mahkemesi Statüsü'ne göre, 1949 Cenevre Sözleşmeleri'nin ağır ihlalleri, savaş hukuku kurallarının ihlalleri, soykırım suçu ve insanlığa karşı işlenen suçlar için bireysel sorumlulukların mahkeme tarafından yargılanacağı hususu tespit edilmiştir. ${ }^{12}$ Nuremberg Mahkemesi'nde organizasyonlar ve gruplar da yargılanabilirken; cezai sorumluluğun bireyselliği ilkesini benimseyen, Eski Yugoslavya Uluslararası Ceza Mahkemesi, yalnızca gerçek kişileri yargılayabilmektedir (Başak, 2003: 38). Yugoslavya Mahkemesi, İkinci Dünya Savaşı'ndan kurulan Nuremberg ve Tokyo Mahkemelerinin aksine sivil bir mahkemedir ve amacı objektif adaleti sağlamaktır. Oysa anılan diğer iki mahkeme, sadece savaşa katılmış belirli bir tarafın askerlerini ve bununla bağlantılı sayılan suçlarını yargılamak üzere kurulmuştur (Önok, 2003: 68). Bu mahkeme, yalnızca bu olayla sınırlı olan yargılama yetkisiyle günümüzde hala yargilamalarına devam etmektedir.

1994 yılında ise Afrika'da, Ruanda'da başlayan etnik kökenli kıyım çerçevesinde işlenen suçları yargılamak için, yine BM tarafından ad hoc nitelikte bir mahkeme kurulmuştur. Ruanda'daki Hutu ve Tutsi kabileleri arasında çıkan iç savaş esnasında, Hutuların Tutsi azınlığına karşı giriştiği soykırım eylemi sonucunda yüz binlerce sivil yaşamını kaybetmiştir (Önok, 2003: 80). Katliamların soykırım derecesine ulaşması üzerine, BM Güvenlik Konseyi, Eski Yugoslavya'da olduğu şekilde, öncelikle BM Genel Sekreteri'nden, Ruanda'daki soykırım ve insancıl hukuk ihlallerini araştırmak için bir komisyon kurulmasını istemiştir (Başak, 2003: 45). Komisyon hazırladığı raporda; Hutuların, Tutsi etnik grubuna yönelik soykırım fiillerini yaygın bir şekilde işlediğine dair birçok delil sunmuş ve bir mahkeme kurulmasını önermiştir. Ruanda Hükümeti de, soykırım ve diğer insancıl hukuk ihlallerinde bulunanların yargılanmasının barışa ve uzlaşmaya katkısının olacağını gerekçe göstererek, yargısal bir mekanizmanın kurulmasını talep etmiştir. BM Güvenlik Konseyi 08.11.1994 ve 955 sayılı kararı ile, Ruanda'daki bu duruma son verilmesi için, 01.01.1994 ve 31.12.1994 tarihleri arasında, Ruanda'da soykırım ve diğer ağır insancıl hukuk ihlalleri gerçekleștiren kişilerin yanı sıra, Ruanda vatandaşlarından, komşu devletlerde, soykırım ve benzeri ihlalleri yapmaktan sorumlu olan kişilerin yargılanmaları için de uluslararası ceza mahkemesi

\footnotetext{
${ }^{11}$ Nuremberg ve Tokyo Mahkemelerinin aksine, Yugoslavya ve Ruanda Savaş Suçluları Mahkemeleri, Birleşmiş Milletler Güvenlik Konseyi tarafından uluslararası toplumun tamamı adına kurulmuștur. Bu iki mahkeme, uluslararası toplumun uluslararası ceza hukuku ve insan hakları hukukunu ihlal eden bireylerin yargılanmalarını sağlamak açısından, insanlık tarihinde ilk defa uluslararası hukuk kurallarına tam anlamıyla uyularak kurulmuş uluslararası ceza mahkemeleri olarak kabul edilmektedir.

${ }^{12}$ Eski Yugoslavya Uluslararası Ceza Mahkemesi, Nuremberg ve Tokyo askeri mahkemeleri duruşmalarından sonra günümze kadar geçen sürede savaş suçlarını işleyen bireylerin yargılanması için kurulan ilk uluslararası mahkemedir.
} 
kurulmasına karar verilmiştir (Çınar, 2004: 24-25). Mahkeme'nin kurulmasının yasal dayanağı, Yugoslavya Mahkemesi'nde olduğu gibi, BM Şartı'nın VII. Bölümü olmuştur (Uzun, 2003: 31). Ayrıca, Ruanda sınırları dışında gerçekleșen katliamların da mahkemenin yarg1 yetkisine dahil edilmiş olmasının sebebi, bu fiilleri işleyen failler arasında Ruanda vatandaşlarının bulunması ve bu çatışmaların Ruanda'daki iç savaşla bağlantılı olarak gerçekleştirilmiş olmasıdır (Başak, 2003: 48). Mahkeme'nin konu bakımından yargı yetkisi ise, soykırım, insanlığa karşı suçlar ve 1949 tarihli Cenevre Sözleşmeleri'nin ortak 3. maddesi ve buna ek olarak Ek II. Protokol'ün ihlalleri ile ilgilidir (Önok, 2003: 84). Bu mahkeme de, hala yargilamalarına devam etmektedir.

Genel olarak bakıldığında, ad hoc mahkemeler, milletlerarası kamuoyunun tepkisini çeken ve ağır suçlar işlemiş bazı suçluların cezalandırılmasını sağlamıştır. Nuremberg Mahkemesi böyle bir uygulamanın ilk örneği olmakla büyük bir öneme sahiptir. Fakat öte yandan, Nuremberg ve Tokyo Uluslararası Ceza Mahkemeleri, pek çoğunda haklılık payı bulunan eleştirilere de maruz kalmıştır. Yugoslavya ve Ruanda Mahkemeleri ise, Nuremberg Mahkemesi'nin eksikliğini taşımamaktadır. Bu mahkemeler bir savaş sonunda galip gelenler tarafindan kurulmamıştır. Her ne kadar bu mahkemelerin kuruluşunun yasal dayanağında bazı tartışmalı noktalar bulunuyorsa da, milletlerarası toplum büyük bir adım atarak Yugoslavya'da ve Ruanda'da yaşanan vahşetin sorumlularını cezalandırma iradesini göstermiştir. $\mathrm{Bu}$ mahkemeler, öncelikle, Soğuk Savaş sonrası dönemde, Nuremberg Mahkemesi'nin bıraktığı mirasın hayata geçirilebileceğini, ağır suçların kovuşturulabileceğini tüm dünyaya göstermiştir. Belirtmek gerekir ki, kurulan bu iki mahkemenin yetkileri yalnızca soruşturdukları olayla sınırlıdır; yani dünyanın başka bir yerinde başka bir zamanda gerçekleştirilecek benzer eylemleri yargılayamazlar (Schabas, 2000: 12). Buna ek olarak, yargılama sürecinde verilmiş olan kararlar ve milletlerarası kamuoyunda yapılan tartışmalar, daimi bir uluslararası ceza mahkemesinin olanaklılığına bir kanıt ve böyle bir mahkemenin nasıl şekilleneceğine ilişkin bir hazırlık çalışması hükmüne geçmiştir (Uzun, 2003: 32).

Daimi nitelikte bir uluslararası ceza mahkemesinin kurulmasına yönelik ilk somut adım, aslında BM Genel Kurulu'nun 4 Aralık 1989 tarihinde Uluslararası Hukuk Komisyonu'ndan uyuşturucu maddelerin yasadışı ticareti ile uğraşan kişileri yargılamak üzere bir uluslararası ceza mahkemesi kurulması hakkında rapor istemesi ile atılmıştır. Genel Kurul, Komisyon'dan 1993 yılında bir taslak statü hazırlanmasını istemiş ve Komisyon da konuyla ilgili çalışmasını bir yıl sonra 1994'te tamamlamıştır. Yine 1994 yılı içerisinde Genel Kurul, Komisyon'un taslak metninin gözden geçirilmesi için $A d$ Hoc Komite kurmuştur. Çalışmalarını tamamlayan Komite 1996, 1997, 1998 yıllarında toplanan bir hazırlık komisyonu tarafından izlenmiştir. Son olarak Uluslararası Ceza Mahkemesi Kurulmasına İlişkin Tam Yetkili Temsilcilerden Oluşan Birleşmiş Milletler Diplomatik Konferansı, 15 Haziran 1998 tarihinde 160 devletin, 33 uluslararası örgütün ve 238 hükümet-dışı örgütün katılımı ile Roma'da toplanmıştır. Konferansın sonunda oluşturulan 17.07.1998 tarihli Sonuç Belgesi ile 120 devletin kabul, 7 devletin aleyhte $^{13}$ ve 21 devletin çekimser oyu (Önok, 2003: 102) ${ }^{14}$ ile Uluslararası Ceza Mahkemesi Roma Statüsü ${ }^{15}$ oy çokluğu ile kabul edilmiştir (Ekşi, 2004: 9-13).

\footnotetext{
13 Oylama gizli olarak yapıldığı için hangi devletlerin red oyu verdiği kesin olarak bilinmemekle birlikte, konferansa katılan delege ve gözlemcilerin görüşlerine göre 7 red oyunun şu ülkelerin içinde bulunduğu bir listeden geldiği düşünülmektedir: ABD, Çin Halk Cumhuriyeti, Hindistan, Irak, İsrail, Libya, Katar, Yemen, Vietnam. Bu ülkelerden ABD, İsrail, Çin, Irak ve Katar konferanstan sonra red oyu verdiğini deklare etmişlerdir. Statüye taraf olma konusunda en büyük direnci ABD’nin gösterdiği söylenebilir. Bugün dünya üzerindeki 70'den fazla ülkede Amerikan askerlerinin varlığ 1 düşünülmektedir. Bu kadar çok sayıda ve geniş coğrafyada faaliyet gösteren Amerikan askeri varlığı başta savaş suçları olmak üzere Mahkeme'nin yargılama yetkisi altındaki suçları işlemeye en yakın askeri güç konumundadır. Siyasi olarak, genel anlamıyla Mahkeme kapsamındaki bir hukuki denetimin Amerikan çıkarlarına aykırı olacağının yanı sıra, hukuki olarak aşağıda sayılan gerekçelerle ABD, Roma Statüs'ne taraf olmamaktadır. Öncelikle ABD, Mahkeme'nin çok fazla kontrol
} 
Roma Statüsü'nde, mahkemenin 60 devlet tarafından onaylanması şartıyla hayat bulacağını belirtiyordu. Bilindiği üzere uluslararası hukukta, bir devletin bir uluslararası antlaşmayı imzalaması yetmemekte, imzalanmış metnin o devletin ilgili mercileri tarafından onaylanması da gerekmektedir. ${ }^{16} \mathrm{Bu} 60$. onay 2002 y1lında gerçekleşmiş ve mahkemenin yarg1 yetkisi de 1 Temmuz 2002 itibariyle başlamıştır. ${ }^{17}$

\section{Uluslararası Ceza Mahkemesi’nin Yargılama Yetkisi}

Uluslararası Ceza Mahkemesi, uluslararası toplumun tümünü ilgilendiren en ağır suçları işleyen kişileri yargılamak için oluşturulan ve çok taraflı bir antlaşma ile kurulan daimi bir uluslararası kuruluştur. $\mathrm{Bu}$ yönü ile önceki mahkemelerden ayrılmaktadır. Nuremberg Uluslararası Ceza Mahkemesi de antlaşma ile kurulmasına rağmen, mahkemeyi kuran antlaşma, sadece savaştan galip çıkan devletler arasında yapılan bir antlaşmaydı. Tokyo Mahkemesi de, General MacArthur'un bir emri ile kurulmuştu. Yugoslavya ve Ruanda Mahkemeleri, diğerlerinden farklı olarak Birleşmiş Milletler Güvenlik Konseyi tarafından kurulmuşlardı. Uluslararası Ceza Mahkemesi ise diğer mahkemelerin aksine belirli bir zaman diliminde ve belirli bir duruma ilişkin kurulmamıştır. Bu yüzden önceki mahkemelerin aksine yarg1 yetkisi yer ve zaman bakımından sınırlandırılmamıştır. Birleşmiş Milletler, Uluslararası Ceza Mahkemesi Statüsü'nün hazırlanması sürecinde aktif rol oynamasına ve Mahkeme Statüsü'nde Birleşmiş Milletler ile bağlantılı hükümler bulunmasına rağmen, yeni ortaya çıkan bu evrensel ceza kuruluşu, BM'nin bir organı değildir. Mahkeme, sadece taraf devletler açısından bağlayıcı olan antlaşmaya dayalı bir kuruluştur. Yani "supranational"18 (Dağ, 2004) nitelikte değil, uluslararası niteliktedir (Ekşi, 2004: 29).

Uluslararası Ceza Mahkemesi'nin en temel özelliklerinden birisi, yarg1 yetkisinin ulusal mahkemelerin yarg1 yetkisini tamamlayıcı nitelikte olmasıdır. Mahkeme, yarg1 yetkisindeki suçları soruşturma ve kovuşturma bakımından devletlere göre ikincil konumdadır. Roma

edilemeyen bir güce sahip olduğuna inanmaktadır ve Mahkeme Savcısı'nın kontrol edilememesinden endişelenmektedir. Ayrıca, Mahkeme'nin günün birinde ABD liderlerini "saldırı suçu"ndan ötürü yargılayabileceğinden endişe edilmektedir. Özellikle Mahkeme'nin ABD liderleri ve askerlerine karşı siyasi olarak yanlı davranacağından endişe edilmektedir.

14 Çekimser oy veren 21 ülkeden birisi de Türkiye'dir. Türkiye, Mahkeme'yi kuran Roma Statüsü'nü imzalamamış ve onaylamamıştır. Türkiye, Roma Statüsü’nü imzalamamış olmakla beraber, Sonuç Belgesi'ni imzalamıştır. Sonuç Belgesini imzalayan ülkelere tanınan imkan paralelinde, Sonuç Belgesi ile kurulan Hazırlık Komisyonu'nun çalışmalarına katılma hakkını elde etmiştir. Bu çalışmalarda terör suçunun Mahkeme'nin yargı yetkisine dahil edilmesi ve bazı suç tanımlarının belirsiz olduğu konularında görüş bildirmiştir. Esasında Güneydoğu Anadolu'da devam eden çatışma ortamı ve bu ortamdan kaynaklanabilecek olası suçlar, Türkiye'nin Statü'ye taraf olmamasında önemli rol oynamaktadır. Türkiye'nin Statüye taraf olmama gerekçelerinden biri de, Kıbrıs meselesiyle bağlantılı olarak savaş suçları ve saldırı suçu konusunda düğümlenmektedir. Buradaki en önemli nokta ise, 1974 Kıbrıs Çıkartması'nda sonra, halen adadaki askeri varlığını devam ettiren Türkiye'nin tutumudur. Her ne kadar ilk bakışta 1974 yılında yaşanan çatışmanın Mahkeme'nin yargı yetkisi dışında kaldığı düşünülse bile, Kıbrıs Rum Kesimi ve Yunanistan'ın aksi fikirde olduğu konusunda ciddi emarelere rastlanmaktadır. Türkiye'nin 1974'de adaya uluslararası hukuka aykırı olarak asker çıkartarak saldırı suçu işlemeye başladığı, halen adadaki Türk askeri varlığı devam etmekte olduğu için, suçun bu zamana kadar mütemadiyen işlenmesine devam edildiği, halen de işlenmekte olduğu, bununla birlikte akıbeti hakkında bilgi olmayan kayıp şahıslar hakkında da ihlallerin hala devam ettiğinden hem savaş suçlarından hem de saldırı suçundan ötürü takibat yapılması gerektiği iddia edilmektedir.

15 Roma Statüsü, söz konusu uluslararası nitelikteki suçları, mahkemenin yapısını ve nasıl çalışacağını, devletlerin mahkeme ile işbirliği için ne yapmaları gerektiğini tanımlayan en temel hukuk belgesidir.

${ }^{16} 31$ Aralık 2000 tarihine kadar Statü imzaya açık kalmıştır ve bu tarihe kadar 139 ülke imzalamıştır. Bu tarihten sonra Statü'nün 125. maddesi uyarınca Statü’yü imzalamak mümkün değildir, ancak onaylama suretiyle Statü’ye taraf olunabilir.

${ }^{17}$ Roma Statüsü'nü 30.07.2014 itibariyle 139 ülke imzalamış, 122 ülke onaylamıștır.

${ }^{18}$ Supranational terimi, devletleri aşan, devletlerin üstünde bulunan ve onların egemenlik yetkilerini kısıtlayan bir kavramdır. 
Statüsü'nde yer alan düzenlemeye göre, eğer Statü'de öngörülen bir suç, yetkili bir devlette kovuşturma ya da soruşturma konusu yapılmış ise, ilgili devletin bunu devam ettirme istek ve yeteneği olmaması durumları hariç, Uluslararası Ceza Mahkemesi'nin yarg1 yetkisi (non bis in idem) söz konusu olmamaktadır (Halatçı, 2005: 57). ${ }^{19}$ Bir başka deyişle; ulusal mahkemelerin Uluslararası Ceza Mahkemesi'ne oranla bir önceliği bulunmaktadır (Aksar, 2005a: 8). ${ }^{20}$ Ulusal mahkemeler, yargilanan suçlar konusunda her zaman yargılama yetkisine öncelikle sahip olacaktır. Mahkeme, egemen bir devletin yargılama yetkisini elinden almaz, bu yüzden Roma Statüsü'nde adına “tamamlayıcılık ilkesi” denen bir ilke getirilmiştir. Buna göre, Mahkeme sadece ulusal mahkemeler yargılama konusunda isteksiz veya görevini ifa edemez durumdayken rol alabilir. Hükümetler, özellikle yüksek mevkide olan kendi vatandaşlarına soruşturma açma konusunda isteksiz olabilirler veya iç çatışma sonucu ceza muhakemesi sisteminin çöktügü yerlerde bu tür suçlarla ilgilenebilecek yetkili bir mahkeme bulunmayabilir. İşte bu gibi durumlarda tamamlayıcıllk ilkesi devreye girecek ve Mahkeme'nin yargılama yetkisi söz konusu olabilecektir. Yani, Mahkeme'nin yargılama yetkisi ikincil konumdadır, birincil yargılama yetkisi her zaman ilgili devlettedir.

Sadece iki durumda, yani ulusal yargılama mercilerinin kovuşturma konusunda isteksiz olmaları ya da buna gerçekten muktedir olmamaları ihtimallerinde Mahkeme, ulusal mercilerin yerine devreye girip, yargilama yapma görevini devralabilecektir. Diğer bir deyişle, ulusal sistemlerin, uluslararası adaletin gerekli kıldığı doğruluk ve dürüstlükte bir yargılama yapmaya niyetli ya da muktedir olmadıkları durumda, onların açıklarını kapatmak üzere Mahkeme'nin yargı yetkisi devreye girecektir. Ayrıca, suçluyu korumaya çalışabilecek bir devletin, Mahkeme'nin yargılanmasından kaçınmak için kendi ulusal yargı sistemiyle suçlunun ceza almasını engellemek için oyalayıcı bir prosedürü işlettirdiğinin anlaşılması üzerine, Mahkeme'nin tamamlayıcı yargı yetkisini kullanarak, yargılamada bulunmasını da mümkün k1lmaktadır (Başak, 2003: 61-62; Önok, 2003: 140). ${ }^{21}$ Öte yandan, eğer herhangi bir devlet, Mahkeme'nin yargilamasına izin vermek istemiyorsa, kendi mahkemelerinde yargılanmak suretiyle, mahkemenin yargilamasına engel olabilecektir.

Mahkeme, şu durumlarda kişiler hakkında soruşturma açmak için yetkili kılınmıştır:

- Suçlar, Roma Statüsü'ne taraf bir devletin sınırları içinde işlendiğinde;

- Suçlar, Roma Statüsü’ne taraf bir devletin vatandaşı tarafından işlendiğinde;

\footnotetext{
${ }^{19} \mathrm{Bu}$ ilke evrensel niteliği haiz bir prensip olmakla birlikte, Avrupa İnsan Hakları Sözleşmesi'nde yer almış ve "hiç kimse bir devletin ceza yargılaması usulüne ve yasaya uygun olarak kesin bir hükümle kabul edildiği veya beraat ettiği bir suçtan dolayı aynı devletin yargısal mercileri tarafından yargılanamaz ve cezalandırılamaz" şeklinde düzenlenmiştir. Bu düzenleme sadece ulusal yargılama alanında geçerlidir. Mahkeme Statüsü'nde ise söz konusu kural, ulusal mahkemeler ile Uluslararası Ceza Mahkemesi arasında geçerli olacaktır. Yani bir birey, daha önce Statü kapsamında yer alan suçlar nedeniyle ulusal bir mahkemede yargılanmış ise Uluslararası Ceza Mahkemesi'nde; Uluslararası Ceza Mahkemesi'nde yargılanmış ise ulusal mahkemelerde yargılanamayacaktır.

${ }^{20}$ Esasında böyle bir düzenlemenin olması, uluslararası hukukta yer alan devletlerin hükümranlığ doğal bir sonucudur. Çünkü tarihsel olarak hükümranlık hakkı ve cezai yarg1 yetkisi birbiriyle yakından ilgilidir ve devletlerin bağımsızlığının ve hükümranlığının bir unsuru olarak kabul edilmektedir.

${ }^{21}$ Tamamlayıcılık ilkesinin amacı, uluslararası suçlar üzerinde rekabet eden ve çatışan birden çok yargılama yetkisi arasında uyum sağlamaktır. Uluslararası Ceza Mahkemesi bakımından da bu uyum, ulusal yargı yetkisine üstünlük tanımak suretiyle, rekabet eden bu yetkiler arasında bir öncelik sıralaması tesis etmek suretiyle sağlanmak istenmiştir. Böyle bir ilkeye yer verilmesi, politik ve pragmatik bir yaklaşımın sonucudur. Bu ilkenin getirdiği anlayış, yargı yetkisine giren suçlar bakımından Mahkeme'nin bir son çare merci olduğunu ortaya koymakta ve böylece, devletlerin tam ve münhasır egemenliklerinin bir uzantısı olan yargılama hakkının da, Mahkeme tarafından gasp edilemeyeceği açıklanmış bulunmaktadır. Mahkeme'nin yargı yetkisinin tamamlayıc1/ikincil niteliği, Mahkeme'nin bu kadar çok devlet tarafından kabul görmesinin en önemli sebeplerinden biridir.
} 
- İstisnai olarak, Roma Statüsü’nü onaylamayan bir devlet, suç karşısında mahkemenin yarg1 yetkisini kabul ettiğine dair bir bildirimde bulunduğunda;

- İstisnai olarak, suçlar uluslararası barış ve güvenliğin tehdit veya ihlal edildiği durumlarda işlendiğinde ve BM Güvenlik Konseyi durumu BM Şartı Bölüm 7'ye uygun şekilde mahkemeye gönderdiğinde.

Mahkeme'nin yargı yetkisinin doğması için, suç teşkil ettiği iddia edilen fiilin, Roma Statüsü'ne taraf olan bir devletin ülkesi üzerinde işlenmiş olması gerekmektedir. Söz konusu fiil, bir deniz ya da hava nakil vasıtası içerisinde işlenmişse, bu nakil aracının bayrağını taşıdığ 1 (tescil edildiği) devlet, Statü’ye taraf olmalıdır. Alternatif olarak şüphelinin vatandaşı bulunduğu devletin Statü'ye taraf olması da Mahkeme'nin yargı yetkisini kullanabilir hale gelmesini sağlayacaktır. ${ }^{22}$ Öte yandan, Roma Statüsü'ne taraf olmayan bir devletin vatandaş1 da, şayet fiilini taraf bir devletin ülkesi üzerinde işlemişse, Mahkeme önünde yargılanabilecektir. ${ }^{23}$ Bunun dışında bir ihtimal daha bulunmaktadır. Eğer, ülkesinde söz konusu fiilin işlendiği ya da Statü'nün kapsamında bulunan bir fiili işleyen failin vatandaşlığında bulunduğu devlet, Statü'ye taraf olmamakla birlikte, bu somut olay için Mahkeme'nin yarg1 yetkisini kabul ederse yine yargılama yapabilecektir. ${ }^{24}$ (Önok, 2003: 143144). Bu halde, somut olay bakımından Mahkeme'nin yargı yetkisini tanıyan bu devlet, gecikme göstermeksizin ve istisna olmaksızın, Mahkeme ile işbirliği gösterecektir. ${ }^{25}$

\subsection{Kişi Bakımından Yargı Yetkisi}

Ceza mahkemelerinin belirli kişisel özelliklere sahip failleri yargılayabileceği hususunda, statüsülerinde yer alan belirleyici düzenlemelere kişi bakımından yarg1 yetkisi denmektedir (Çınar, 2004: 48). Kişi bakımından yetki, özellikle Uluslararası Ceza Mahkemesi'nin yargı yetkisindeki suçları işlemesi muhtemel kimselerin genellikle diplomatik ya da bağıșıklık düzenlemelerinden faydalanma ihtimalleri göz önüne alındığ 1 takdirde büyük önem taşımaktadır (Uzun, 2003: 40).

Uluslararası Ceza Mahkemesi'nde, bireysel sorumluluk ilkesi esastır ve yalnızca gerçek kişiler yargılanabilir. Mahkeme, devletleri yargilayamaz. Bu durumun temel nedeni, devletin tüzel kişiliğinin yargılanamaz, yargılansa bile bir ceza ile karşılaşamaz oluşundan kaynaklanır. $\mathrm{Bu}$ durumda mahkemenin yargılama yetkisine giren suçların işlendiği iddia edildiğinde, bu suçları işleyen gerçek kişilere dava açılacaktır. Bu gerçek kişiler, bizzat suçu işleyenden suç işlenmesi emri verene, en alt düzeyde suça iştirak edenden en üst düzet devlet görevlilerine, cumhurbaşkanı, başbakan, bakanlar, genelkurmay başkanına kadar uzanabilir. Mahkeme, ulusal hukuktan kaynaklanan hiçbir bağışıklık ya da dokunulmazlıkla kendisini bağlı saymaz.

Uluslararası Ceza Mahkemesi Roma Statüsü’nün 1. maddesinde belirtildiği gibi Mahkeme, uluslararası toplumun tümünü ilgilendiren en ağır suçları işleyen sadece gerçek kişiler üzerinde yargı yetkisini kullanmaya yetkilidir. Bu yönü ile gerçek kişiler yanında örgüt ve grupları da yargılama yetkisine sahip olan Nuremberg Mahkemesi'nin gerisinde kalırken, kişi

\footnotetext{
${ }^{22}$ Uluslararası Ceza Mahkemesi Statüsü mad. 12/2.

$23 \mathrm{Bu}$ açıdan bakıldığında, Türkiye Roma Statüsü’nü imzalamamış olsa da, bir Türk vatandaşı, Statü kapsamındaki bir fiili, Statü'ye taraf bir devletin ülkesinde işlemişse, Mahkeme tarafından yargılanabilecektir.

24 Örneğin, ileride Ege Denizi’nde yaşanan bir kriz sonucunda, Yunanistan ile Türkiye arasında, belirli bir adacığın kimin egemenliği altında olduğuna dair bir uyuşmazlık çıkacak olursa ve Yunanistan'ın bu adacığa kendi bayrağını dikmesi üzerine, Bakanlar Kurulu kararıyla oraya Türk askerleri gönderilse ve Türk bayrağı dikilse, bunun üzerine de, Yunanistan, Uluslararası Ceza Mahkemesi Savcısına başvurup kendi egemenliğini ihlal eden bir saldırı fiilini yaşandığını belirtse, Yunanistan, Mayıs 2002 itibariyle Roma Statüsü'ne taraf olduğundan, bu Türk askerleri Uluslararası Ceza Mahkemesi tarafından yargılanabilecektir.

${ }^{25}$ Uluslararası Ceza Mahkemesi Statüsü mad. 12/3.
} 
bakımından yargı yetkileri gerçek kişilerle sınırlandırılmış olan Yugoslavya ve Ruanda Mahkemeleri ile paralellik taşımaktadır. Öte yandan, Mahkeme'nin kişi bakımından yetkisinin sadece gerçek kişilerle sınırlandırılmış olması, devletler veya tüzel kişiler üzerinde yargı yetkisi kullanamayacağı sonucunu ortaya çıkarmaktadır. Fakat Mahkeme, devletler üzerinde yarg1 yetkisine sahip olmasa da, yargıladığı gerçek kişilerle bağlantılı olarak devletlerin, özellikle resmi görevlileri aracılığıyla yürüttükleri fiilleri değerlendirme imkanına sahip olmaktadır (Ekşi, 2004: 32-33).

Öte yandan, Roma Statüsü'nde kişiler bakımından da önemli bir istisna vardır: Fiilin işlendiği zaman 18 yaşını doldurmamış olan kimseler üzerinde yarg1 yetkisi kullanılamayacaktır. Bir başka deyişle, Roma Statüsü, kişisel özelliklerden yaş unsurunu esas olarak yargı yetkisini sınırlamaktadır. Buna göre suçun ișlendiği tarihte 18 yașın altında olan hiçbir şahıs cezai ehliyeti olmaması nedeniyle Mahkeme tarafından yargılanamayacaktır. ${ }^{26}$ Ayrıca, askeri bir komutan veya askeri komutan gibi etkin bir şekilde davranan kişilerin cezai sorumluluğu konusunda da özel bir düzenleme getirilmiştir. $\mathrm{Bu}$ kişilerin sorumluluğunun, kendi fiili yönetimi ve denetimi altında bulunan silahlı kuvvetlerin eylemleri paralelinde oldukça geniş tutulduğu gözlenmektedir (Çınar, 2004: 49).

Uluslararası Ceza Mahkemesi Roma Statüsü çerçevesinde Mahkeme'nin yargı yetkisine giren suçlarla bağlantılı olarak gerçek kişilerin bireysel cezai sorumluluğu, sadece bizzat suçu işlemelerinden kaynaklanmamaktadır. Bireylerin cezai sorumluluğu ile ilgili ayrıntılar madde 25/3'te düzenlenmektedir. Söz konusu madde çerçevesinde Mahkeme, yarg1 yetkisine giren suçlarla ilgili olarak bizzat suçu işleyen kişiler yanında işlenmesini emreden, isteyen veya özendiren, suçun işlenmesine yardımcı veya ortak yanı olan ya da herhangi bir biçimde suçun işlenmesine veya teşebbüsüne katılan kişiler üzerinde de yargılama yetkisine sahip olacaktır (Ekşi, 2004: 35).

Roma Statüsü, resmi makama dayalı herhangi bir ayrım gözetmeksizin herkese eşit olarak uygulanacağını öngörmektedir. Devlet başkanı veya hükümet başkanı, hükümetin veya parlamentonun üyesi veya seçilmiş temsilci veya hükümet yetkilisi olarak herhangi bir resmi görevde olmak, cezai sorumluluktan muaf tutulması veya tek başına cezanın hükmünde indirimde bulunulması için neden teşkil etmeyecektir. ${ }^{27}$ Öte yandan, uluslararası hukuk çerçevesinde bazı kişilere ayrıcalık ve bağışıklıklar da verilmektedir. Özellikle Uluslararası Ceza Mahkemesi Statüsü'ne taraf olmayan bir devletin diplomatik personelinin, Statü'ye taraf olan kabul eden devletin ülkesinde Mahkeme'nin yargı yetkisine giren bir suçu işlemesi durumunda, Mahkeme'nin söz konusu kişi üzerinde yarg1 yetkisini kullanıp kullanamayacağı sorununa bakacak olursak, eğer diplomatik personeli gönderen devlet Statü'ye taraf değilse, söz konusu devlet bağışıklık konusunda feragatta bulunmadığ 1 sürece, ilgili kişinin Mahkeme'ye teslim edilmesi mümkün görünmemektedir.

Roma Statüsü 31. maddede, bireysel cezai sorumluluğu ortadan kaldıran nedenler bulunmaktadır. Söz konusu maddede sayılan nedenlerin ilgili kişinin cezai sorumluluğunu ortadan kaldırabilmeleri için eylem zamanında mevcut olmaları gerekmektedir. Nedenlerden ilki, kişinin eyleminin hukuka aykırılığını veya doğasını değerlendirme ya da eylemini hukukun gereklerine uyacak biçimde kontrol etme yeteneğini yok eden akıl hastalığ veya sakatlığına yakalanmış olmasıdır. İkinci bir neden, kişinin eyleminin hukuka aykırılığını kontrol etme yeteneğini yok eden zehirleyici maddenin etkisi altında olması durumudur. Başka bir neden de, kişinin veya diğer bir kişinin veya savaş suçları durumunda kendisinin veya başka bir kişinin hayatta kalması için gerekli olan bir malı ya da askeri bir görevi tamamlamak için gerekli olan bir malı, derhal vuku bulabilecek ve hukuka aykırı bir kuvvet

\footnotetext{
${ }^{26}$ Uluslararası Ceza Mahkemesi Statüsü mad. 26.

${ }^{27}$ Uluslararası Ceza Mahkemesi Statüsü mad. 27/1.
} 
kullanımına karşı korumak için makul olarak giriştiği eylemlerdir. Cezai sorumluluğu ortadan kaldıran nedenlerden sonuncusu ise, zorunluluk halidir (Ekşi, 2004: 39-40).

\subsection{Konu Bakımından Yargı Yetkisi}

Ceza mahkemelerinin belirli suç fiilleri konusunda veya maddi olaylar hakkında yargılama yapabilmesine dayanak oluşturan ve bu mahkemelerin statülerinde düzenlenmiş olan yetkiye konu bakımından yargı yetkisi denmektedir (Çınar, 2004: 46).

Uluslararası Ceza Mahkemesi Statüsü'nün 5. maddesinde, uluslararası suç olarak tanımlanmış suç tipleri; soykırım, insanlığa karşı suçlar, savaş suçları ve saldırı suçlarıdır. Söz konusu suçlar, özleri ve neticeleri itibariyle haince bir yapıya sahiptir ve bütün devletlerin menfaatlerini ilgilendirirler. Diğer bir deyişle bu tür suçlar, uluslararası toplumun temelini oluşturan yapı taşlarını zedeleyen ve bunların esasını teşkil eden değerleri tehdit eden suçlardır. Örneğin soykırım suçu, insan gruplarının yok edilmesine dayanan bir fiil olarak, insanoğlunun varlığının devamını tehlike altına sokan bir suçtur. Ayrıca belirli bir grubu ortadan kaldırmayı hedeflediğinden, söz konusu kitlenin insanlığa yapabileceği katkıları da yok ederek, bir bütün olarak medeniyeti kayba uğratmaktadır. İnsanlığa karşı suçlar, adam öldürme, topyekun imha, işkence, rrza geçme gibi tarif edilemez vahşette fiillerden oluşmakta ve insanoğlunun en temel değeri olan kişi haysiyeti ve dokunulmazlığını hiçe saymaktadır. Savaş suçları da keza, yukarıdaki iki suç için belirtilen tüm tehlikeli sonuçları doğurabilmektedir. Saldırı suçu ise, "uluslararası suçların babası" olarak, sadece insanlığın barış ve güven içinde yaşamasını tehlikeye düşürmekle kalmıyor, aynı zamanda "en vahim insan hakları ihlallerinin yetişmesine imkan sağlayan toprağ 1 " temin etmektedir (Önok, 2003: 149).

\subsubsection{Soykırım Suçu}

Soykırım sözü, ilk kez 1944 yılında, Polonyalı bir hukukçu olan Rafael Lempkin'nin “Axis Rule in Occupied Europe" adlı kitabında geçerek uluslararası hukuk literatürüne girmiştir. Soykırım kelimesi, Yunanca 1rk, ulus ya da soy anlamına gelen "genos" kelimesi ile Latince öldürme anlamında kullanılan "cide" son ekinin birleşmesiyle oluşmuş, iki ayrı dilden alınmış kelimelerle yapılan bileşik bir kelimedir (Prevent Genocide International, http://www.preventgenocide.org/lemkin/AxisRule1944-1.htm).

Soykırım suçu dünya üzerinde işlenebilen en ağır suçlardan biridir. Soykırım suçu, her zaman etnik özellikler göstermeyen, başka özellikleri ile de tanımlanabilen bir gruba karşı işlenen metodik ve sistematik insanlık suçudur. Soykırım, uluslararası kriterler açısından çok teknik olarak değerlendirilen ve uluslararası insancıl hukuk kuralları içinde en ağır ihlallerin başında sayılan önemli bir suç olarak kabul edilmektedir.

Soykırım suçu, ilk kez 1948 tarihli Soykırım Suçunun Önlenmesi ve Cezalandırılması Sözleşmesi'nde (Soykırım Sözleşmesi) tanımlanmıştır. Buna göre soykırım, etnik, dinsel, ulusal ya da irksal bir grubun tamamını veya bir kısmını yok etmeyi amaçlayan ve Sözleşme'de sayılan birtakım eylemleri ifade etmektedir. Uluslararası Ceza Mahkemesi'ni kuran Roma Statüsü'nün 6. maddesi, Soykırım Sözleşmesi'nde tanımlanan soykırım suçunu aynen benimseyerek, yargılama yetkisini Uluslararası Ceza Mahkemesi'ne vermiştir. Bu tanımlama, uluslararası örf ve adet hukukunun emredici bir kuralı olarak (jus cogens) kabul edilmiştir. Bu nedenle Soykırım Sözleşmesi'ni onaylamış olsun olmasın, tüm devletler için bağlayıcıdır. Diğer bir deyişle, Sözleşme'ye taraf olan devletler, soykırımın uluslararası hukuka göre bir suç olduğunu kabul etmişlerdir. Soykırım Sözleşmesi'ne taraf olmayan devletler bakımından ise, Sözleşme'ye dayalı bir sorumlulukları olmamalarına rağmen, Uluslararası Adalet Divanı söz konusu kuralların onlar açısından da bağlayıcı olduğunu ifade etmiştir. Sonuç olarak Sözleşme, kendisinden önceki uluslararası suçlarla ilgili 
gerçekleştirilmiş olan düzenlemelerde bulunmayan yeni bir anlayışı ortaya koymuştur (Başak, 2003: 72; Azarkan, 2003: 23). ${ }^{28}$

Soykırım suçu, Uluslararası Ceza Mahkemesi Roma Statüsü'nde "ulusal, etnik, rrki veya dini bir grubu, kısmen veya tamamen yok etmek amacıyla aşağıdaki fillerin işlenmesidir." olarak tanımlanmıştır. Bu fiiller şunlardır:

a) Grup üyelerini öldürmek,

b) Grup üyelerine ciddi bedensel ya da zihinsel zarar vermek,

c) Grubu kısmen ya da tamamen fiziksel tahribine yol açacağı hesaplanan yaşam şartlarına kasıtlı olarak maruz birakmak,

d) Grup içinde doğumları önlemeye yönelik tedbir almak,

e) Grubun çocuklarını zorla başka bir gruba nakletmek.

"Grup üyelerini öldürmek”, bir veya daha fazla kişinin öldürülmesi veya ölümüne yol açılması; "grup üyelerine ciddi bedensel ya da zihinsel zarar vermek", işkence, 1rza geçme, cinsel şiddet veya insanlık dışı ya da küçük düşürücü muamele de dahil olmak ve bunlarla sınırlı olmamak üzere, bir veya daha fazla kişiye ciddi bedensel veya ruhsal zararlar veren davranışlarda bulunmak; "grubu kısmen ya da tamamen fiziksel tahribine yol açacağı hesaplanan yaşam şartlarına kasıtlı olarak maruz bırakmak", büyük önem taşıyan gıda ve tıbbi bakım gibi imkanlardan kasten yoksun bırakmak veya evlerden sistematik kovulma da dahil olmak ve bunlarla sınırlı olmak üzere, grubun kısmen veya tamamen fiziksel yıkımına yol açacağı hesaplanan yaşam şartlarına bir ya da daha fazla kimseyi tabi tutma; "grup içinde doğumları önlemeye yönelik tedbir almak", bu amaca yönelik tedbirlerin bir veya daha fazla kişiye uygulanması, "grubun çocuklarını zorla başka bir gruba nakletmek", 18 yaşın altında olan ve failin bu durumu bildiği veya bilmesi gerektiği bir veya daha çok kimseyi bir gruptan diğerine zorla nakletmesi anlamına gelmektedir (Aksar, 2004: 203).

Statünün 25. maddesine göre, soykırım suçu işleyen ya da işlemeye teşebbüs eden birine bu suçun işlenmesini emreden, suça teşvik veya tahrik eden herkes soykırım suçlusudur. Yine bu maddeye göre, bir başkasının soykırım suçu işlemesine veya işlemeye teşebbüs etmesine yardım eden, cesaret veren herkes soykırım suçlusudur. Ayrıca bu madde uyarınca bir kimsenin doğrudan ve alenen diğerlerini soykırım suçu işlemeye kışkırtması da soykırım suçunu oluşturur. Soykırım Sözleşmesinin 3. maddesinin tersine, soykırım yapmak için gizlice anlaşmak (komplo kurmak) da Statü'nün 6. maddesinde açıça bir suç olarak tanımlanmamasına rağmen, Statü'nün 25. maddesi bu eylemi de suç olarak kabul etmiştir.

Soykırım suçunun oluşması için bir grubun tamamen ya da bir bölümünün yok edilmesi gerekmez. Suçun oluşabilmesi için herhangi bir sayı şartı da yoktur. Burada soykırım amacını taşımak, yani kast unsurunun bulunması önemlidir. Bu amaç ile hareket edilmişse, örneğin bir tek kişinin öldürülmesi bile soykırım suçunu oluşturabilir; meğer ki soykırım kastı ispatlanabilsin. Sadece soykırımı planlayan ve yapılmasını emreden bir devlet başkanı ya da hükümet bakanı değil, suçu işleyen sıradan bir asker veya işlenmesine göz yumarak katılan bir başka birey de soykırım suçunun faili olabilir.

\footnotetext{
28 İkinci Dünya Savaşı Sonrası dönemde uluslararası insan hakları hukukunda meydana gelen gelişmeler, bireysel sorumluluğun hukuksal çerçevesinin çiziminde önemli aşamaların kaydedilmesini sağlamıştır. 1948 tarihli "Birleşmiş Milletler Soykırım Sözleşmesi”" bunun en güzel örneğini oluşturmuştur. Barış zamanında yapılan bu sözleşme, soykırıma ilişkin bireysel sorumluluğun çerçevesini çizmiştir. Soykırım Sözleşmesi, birçok devlet tarafından onaylanmış; soykırım ve bireysel sorumluluğa ilişkin düzenlemeleri, teamül hukuku ve hukukun genel ilkelerinin bir parçası haline getirmiştir.
} 


\subsection{2. İnsanlığa Karşı İşlenen Suçlar}

İkinci Dünya Savaşı'nın en önemli sonuçlarından bir tanesi de tarihte ilk defa, Nuremberg ve Tokyo Uluslararası Ceza Mahkemeleri'ne ilişkin düzenleme ve uygulamalar aracılığıyla, insanlığa karşı işlenen suç kavramının uluslararası ceza hukukuna kazandırılmasıdır. Böyle bağımsız bir suç kategorisinin yaratılmasının temel nedeni, barış zamanında işlenilen bazı suçların ya da devletin kendi vatandaşlarına karşı işlediği suçların, savaş suçları veya saldırı suçları kapsamında değerlendirilememesidir (Aksar, 2005a:46).

Bu tür suçların ilk örnekleri Birinci Dünya Savaşının sonunda görülmesine rağmen, 1945'deki Nuremberg Mahkemesi Şartı'na kadar uluslararası bir belgede toplanmadılar. Nuremberg Şartı'nda tanımlandığı haliyle İnsanlığa karşı suçlar, takip eden yıllarda BM Genel Kurulu tarafından uluslararası hukukun bir parçası olarak tanınmış ve Eski Yugoslavya ve Ruanda için Uluslararası Ceza Mahkemeleri Statüleri de dahil olmak üzere, daha sonraki pek çok uluslararası belgede kapsamı belirlenmiştir. Fakat, insanlığa karşı işlenen suçlar, Uluslararası Ceza Mahkemesi'ni kuran Roma Statüsü 17 Temmuz 1998'de kabul edildiğinde ilk kez uluslararası bir antlaşmada tanımlanmış oldu.

Roma Statüsü, insanlığa karşı suçları, sıradan suçlardan sahip olduğu yargılama yetkisinden dolayı üç biçimde ayırmaktadır: Birincisi, insanlığa karşı suçlar başlığı altında işlenen cinayet gibi suç oluşturan eylemler, "geniş ölçekli ve sistematik bir saldırının parçası olarak işlenmiş" olmak zorundadır. Bununla birlikte, buradaki saldırı kelimesi sadece askeri bir saldırı anlamında algılanmamalıdır. Uluslararası örf-adet hukukunda, insanlığa karşı suçun oluşabilmesi için failin gerçekleştireceği suç teşkil eden fiilin sivillere yönelik yaygın ve sistematik saldırıyla bağlantısı olması gerekmektedir. Ayrıca, sınır dışı etmek ve zorla yerinden etmek gibi kanunları ve idari önlemleri de kapsayabilir. İkincisi, eylemler "sivil bir nüfusa karşı yöneltilmek" zorundadır. İnsanlığa karşı suç düzeyine yükselmeyen tek başına, izole, ayrı ya da rasgele eylemler bu sıfatla kovuşturulamaz. Sivil nüfusun arasında çok az sayıdaki askerin varlığı, onları sivil karakterlerinden mahrum etmek için yeterli değildir. Çok geniş bir sivil topluluğun hedef alınmış olması ve insanlığa karşı suç teşkil eden fiilin silahlı çatışma dışında kalan kişilere yönelik bir fiil olarak gerçekleştirilmiş olması gereklidir. Üçüncüsü ise, eylemler "bir devlet ya da organizasyonla ilgili politikaya" uygun bir şekilde gerçekleştirilmiş olmak zorundadır. Bu yüzden, suçlar bizzat devlet görevlileri ya da onların kontrolündeki kişilerin teşvik ettiği eylemler yoluyla ya da onların ittifakı veya rızasıyla işlenebilir. İnsanlığa karşı suçlar, aynı zamanda hükümetle hiçbir bağlantısı bulunmayan, asi gruplar ya da silahlı muhalif örgütler gibi organizasyonların politikalarına uygun olarak da işlenebilir.

Roma Statüsü'nün 7. maddesinde, insanlığa karşı suç olarak nitelendirilen fiiller ise şunlardır:

a) Kasitlı adam öldürme: cinayet suçudur.

b) İmha: Kurbanların imha edilmesidir.

c) Köleleştirme: Bir kişi üzerinde sahiplik gücünü uygulama; bu kişilerin özellikle de kadınların ve çocukların alınıp satılmasını içerir.

d) Nüfusun sürgünü veya zorla nakli: Bireyleri uluslararası hukuk kapsamında izin verilen bir temel olmaksızın, kanunen mevcut bulundukları bir alanı terk etmeye zorlamak; sınır dışı etmek ulusal sınırların karşı tarafına geçirmeyi ve zora dayanarak ulusal sınırlar içinde meydana gelen aktarılmaları içerir.

e) Uluslararası hukukun temel kurallarını ihlal eder bir biçimde hapsetme veya fiziksel özgürlükten diğer biçimde ağır yoksun bırakma. 
f) Irza geçme, cinsel kölelik, zorla fuhuş, zorla hamile bırakma, zorla kısırlaştırma veya benzer ağırlıktaki diğer ağırlıktaki diğer şiddet biçimleri.

g) Politik, ırkçı, ulusal, etnik, kültürel, dinsel, cinsiyet ayrımına veya uluslararası hukuk uyarınca evrensel açıdan izin verilmeyen herhangi diğer bir temele dayalı olarak Mahkeme'nin yargı yetkisine giren suçlardan herhangi biri ile bağlantılı olarak yapılan zulüm.

h) Kişilerin zorla kaybedilmesi: Bir devletin ya da politik bir organizasyonun yetkisi, ittifakı ya da işbirliği ile ya da doğrudan bu yolla kişilerin tutuklanması, gözaltına alınması ya da kaçırılmasını takiben ya özgürlüğünden yoksun bıraktığını reddetmek ya da süregiden bir zaman diliminde kişiyi hukuki korumadan kasıtlı bir şekilde çıkararak "kaybedilen" kişilerin akıbeti hakkındaki bilgiyi vermeyi reddetmek.

i) Apartheid (Irk ayrımcılığg): Irksal bir grubun herhangi bir diğer ırksal grup üzerindeki yönetimini devam ettirme kastı ile uygulanan sistematik baskı ve egemenliğin kurumsallaştırıldığı bir yönetim bağlamında yapılan insanlık dışı eylemler.

j) Kasıtlı olarak büyük acıya veya vücutta ya da zihinsel veya fiziksel sağlıkta ciddi zarara neden olan benzer nitelikteki diğer insanlık dışı fiiller.

k) İşkence: Gözaltında ya da sanıklar kontrol altındayken bir kişiye yönelik ciddi fiziksel ya da zihinsel acıya ya da izdiraba kasitlı olarak neden olmak.

1) Hiç canlı bırakmama emrinde bulunma (Aksar, 2005a: 46).

Roma Statüsü'nde insanlığa karşı suç işleyen fail, sivil topluluğa yönelik kapsamlı saldırıların sorumlusu olmasa bile, en azından bu saldırıların varlığını bilmek zorundadır. Burada önemli olan, failin kendi fiilinin diğer fiillerle bağlantısının bilincinde olarak insanlığa karşı suç eylemini işlemiş olmasıdır.

\subsubsection{Savaş Suçları}

Savaş suçlarının ilk kez kapsamlı bir kanun halinde toplanması, Amerikan İç Savaşı sırasında Başkan Lincoln tarafından 1863'de çıkarılan Lieber Kuralları'nda gerçekleştirilmiştir. O tarihten bu yana savaş suçlarının kapsamlı olarak uluslararası antlaşma zemininde kodifiye edilmesi, 1949 tarihli Cenevre Sözleşmeleri ve bu sözleşmelerin 1977 tarihli protokolleri olmak üzere çok sayıda uluslararası insancıl hukuk sözleşmesinin hazırlanması ile sağlanmıştır. Uluslararası Ceza Mahkemesi Roma Statüsü'nün 8. Maddesi, bu antlaşmalarda ve uluslararası örf ve adet hukukunda tanımlanmış uluslararası silahlı çatışma esnasında işlenen savaş suçlarının büyük bir bölümü üzerinde Uluslararası Ceza Mahkemesi'ne yetki vermektedir (Aslan, 2006: 61).

Roma Konferansı'nda varılan uzlaşma neticesinde mad. 8/1'de Uluslararası Ceza Mahkemesi'nin “özellikle bir planın veya politikanın parçası olarak veya bu tip suçların büyük çapta işlenmesinin bir parçası olarak işlenen" savaş suçları üzerinde yargılama yetkisini kullanabileceği belirtilmektedir. Roma Statüsü'nde uluslararası nitelikteki silahlı çatışmalarla ilgili hükümler yanında, uluslararası nitelikte olmayan silahlı çatışmalarla ilgili hükümler de yer almaktadır (Uzun, 2003: 37). Söz konusu maddeye "özellikle" teriminin dahil edilmesi ile Mahkeme'nin yetkisine giren savaş suçlarının türünün gösterilmesi amaçlanmaktadır. Madde 8/2'de ise dört savaş suçu kategorisi açıklanmaktadır. Bunlar:

a) 12 Ağustos 1949 tarihli Cenevre Sözleşmeleri’nin ağır ihlalleri;

b) Uluslararası hukukun tesis ettiği çerçeve içinde uluslararası çatışmalara uygulanabilir yasa ve geleneklerin diğer ciddi ihlalleri; 
c) Uluslararası nitelikte olmayan silahlı çatışmalarda 12 Ağustos 1949 tarihli Cenevre Sözleşmelerinin ortak 3. maddesinin ciddi ihlalleri;

d) Uluslararası hukukun tesis ettiği çerçeve içinde uluslararası nitelikte olmayan silahlı çatışmalara uygulanabilir yasa ve geleneklerin diğer ciddi ihlalleridir (Ekşi, 2004, 48-49).

Birinci grubu 12 Ağustos 1949 tarihli Cenevre Sözleşmeleri'ne dahil bazı ağır ihlaller oluşturmaktadır. Buna göre; kasten adam öldürme, işkence yapma, insanlık dışı davranışlar ve kasten büyük acılar çektirme gibi eylemler savaş suçu kabul edilmektedir. İkinci grup savaş suçlarını, savaş hukukunu ve buna ilişkin örf ve adet kurallarının ihlali oluşturmaktadır. $\mathrm{Bu}$ bağlamda, kasten sivil topluluklara saldırmak veya savaşla veya savaşla ilgisi olmayan kimselere saldırmak, dini, eğitim, sanat ve tarihi yerler veya hastaneler gibi birimlere saldırmak, zehirli gaz veya silah kullanmak gibi eylemler savaş suçu sayılmaktadır. Üçüncü grup savaş suçlarını ise, uluslararası nitelikte olmayan silahlı çatışmalarda işlenmiş eylemler oluşturmaktadır. Buna örnek olarak, çatışmalarda yer almayan kimselerin öldürülmesi, esir alınması ve işkence yapılması gösterilebilir. Dördüncü grup savaş suçları da yine, uluslararası olmayan silahlı çatışmalarda meydana gelen savaş hukuku ve örf ve adet hukuku kurallarının ciddi ihlallerine ilişkindir. $\mathrm{Bu}$ suçlara ise, kasaba ve köylerin yağma edilmesi, sivil topluluklara saldırması ve ırza tecavüz suçları örnek gösterilebilir.

Roma Statüsü'nde savaş suçları genel olarak iki ana kategoriye ayrılır. Birincisine göre, Uluslararası Ceza Mahkemesi 1949 Cenevre Sözleşmeleri'nin dördünün ağır ihlalleriyle suçlanan kişileri yargılayabilir. Bunlar yaralı askerler, yaralı ya da deniz kazasına uğrayan denizciler, savaş esirleri ve işgal altındaki topraklardaki siviller de dâhil olmak üzere Cenevre Sözleşmeleri tarafından korunan kişilere karşı işlenen kasten öldürme, biyolojik deneyler yapmayı da kapsayan işkence ya da insanlık dışı muamele, kasten dayanılmaz acıya maruz bırakma ya da vücuda veya sağlığa ciddi zarar verme; kanunsuz ve nedensiz bir şekilde ve askeri zorunluluklarla meşrulaştırılamayacak şekilde geniş çapta tahrip etme ve mülke el koyma; savaş esirlerini ya da korunan diğer kişileri düşman devletin silahlı kuvvetlerinde hizmet vermeye zorlama; savaş esirlerini ya da korunan diğer kişileri adil ve kurallara uygun yargılanma hakkından kasıtlı olarak mahrum bakma; hukuk dışı bir şekilde sınır dışı ya da transfer etme ya da kanundışı bir şekilde hapsetme; rehin alma eylemleridir. İkinci olarak Mahkeme, Lahey yönetmeliklerinde ve Cenevre Sözleşmeleri'nin I nolu Protokolü'nde ve uluslararası örf ve adet hukukunda tanımlanmış ihlalleri de içerecek şekilde uluslararası insancıl hukukun diğer ihlallerinin büyük bir kısmı üzerinde yargılama yetkisine sahiptir. $\mathrm{Bu}$ fiiller şunları içermektedir:

- Doğrudan sivil nüfusa, sivil eşyalarına, insani yardıma ya da barış koruyucu misyonların yanı sıra sağlayacağı önceden tahmin edilen somut ve doğrudan doğruya askeri avantaja oranla aşırı bir şekilde sivil hedeflere zarar vereceği ya da sivilleri yaralayacağı ya da rastlantısal olarak can kaybına yol açacağı bilinen saldırılar da dahil olmak üzere sivillere yönelik yasaklanmış saldırılar; Kızılhaç ve Kızılay amblemlerini taşıyan binalara, malzemelere, tıp birimlerine, ulaşım araçlarına ve kişilere karşı saldırılar; ve askeri hedef olmayan din, eğitim, sanat, bilim ya da hayır amaçlarıyla kullanılan binalara, tarihi anıtlara ve hastanelere saldirilar.

- Teslim olmuş askerleri öldürmek ya da yaralamak; uzuv keserek fiziksel olarak sakat bırakmak; kişinin ölüme sebebiyet verecek ya da onun sağlığını ciddi biçimde tehlikeye atacak tıbbi olarak meşrulaştırılamayacak ve kişinin çıkarları doğrultusunda yapılmayan tıbbi ya da bilimsel deneyler gerçekleştirmek; kişinin onuruna yönelik saldırı, özellikle de onur kırıcı ve aşağılayıcı muamele; tecavüz ve cinsel şiddetin diğer biçimleri ve insanları kalkan olarak kullanmak gibi savunmasız kişilere zarar verme. 
- Ateşkes bayrağını, BM ya da düşman işaretini ya da Kızılhaç ve Kızılay amblemlerini kötüye kullanmak; esir alınmayacağını bildirmek; askeri gerekliliklerle meşrulaştırmadıkça düşman mülklerini yağmalama, yok etme ya da zaptetme; zehir ya da zehirli silahlar, belirli gazları, vücutta parçalanan kurşunları ve yapılacak bir değişiklikle tüzüğe eklenecek diğer silahlar gibi yasaklanmış silahları kullanmak; bir savaş yöntemi olarak sivilleri kasten aç bırakmak ya da ulusal silahlı kuvvetlere 15 yaşından küçük çocukları almak ya da onları silahlı çatışmalara aktif bir şekilde katarak kullanmak gibi bazı yasaklanmış savaş yöntemleri.

- İşgalciler tarafından işgal ettikleri topraklara kendi sivil nüfuslarının dolaylı olarak ya da doğrudan transferi ya da işgal edilen toprakların nüfusunun tamamının veya bir parçasının sınır dışı edilmesi ya da transferi; düşman vatandaşlarının yasal haklarını kaldırma ya da askıya alma ya da onları kendi ülkelerine karşı askeri operasyonlara katılmaya zorlamak da dahil olmak üzere, işgal edilen topraklarda ya da düşman vatandaşlarına karşı yasaklanmış bazı eylemler.

Roma Statüsü, uluslararası olmayan silahlı çatışmalar sırasında işlenen savaş suçlarını ise üç ayrı grupta tasnif etmektedir.

- Yaşam ve kişilik haklarının ihlali, özellikle her türlü cinayet, uzuv kesilmesi, zalimane muamele ve işkence; onuruna yönelik yapılan saldırı, özellikle aşağılayıcı ve onur kırıcı muamele; rehin alma; önceden yaygın olarak vazgeçilmez kabul edilen bütün adli garantileri sağlayan ve kurallara uygun bir şekilde oluşturulmuş mahkeme tarafından verilen karar olmaksızın idam hükümlerinin ve infazların gerçekleştirilmesi de dahil olmak üzere sivillere, yaralılara ve gözaltındakilere karşı Cenevre Sözleşmeleri’nin ortak 3. maddesinin ihlalleri.

- Doğrudan sivil nüfusa, Kızılhaç ve Kızılay’ı belirten amblemleri taşıyan binalara, malzemelere, tıp birimlerine ve ulaşım araçları ve kişilere; insani yardım ya da BM barış koruyucu misyonlarına; askeri bir hedef teşkil etmeyen din, eğitim, sanat, bilim ya da hayır işlerinde kullanılmak üzere tahsis edilmiş binalara, tarihi anıtlara, hastanelere yönelik kasten saldırı; yağmalama; tecavüz ve cinsel şiddet suçlarının diğer biçimleri; 15 yaşından küçük çocukları askere veya silahlı gruplara alma ya da onları silahlı çatışmalara aktif bir şekilde katılarak kullanma da dahil olmak üzere Cenevre Sözleşmeleri II nolu Protokol'de genel olarak öngörülen insanc1l hukukunun ihlalleri.

- Düşman savaşçıları hileli bir şekilde öldürmek ya da yaralamak; esir alınmayacağını bildirmek, fiziksel uzuv kesimi ya da tıbbi ya da bilimsel deneyler yapmak; askeri bir zorunlulukla meşrulaştırılmadıkça bir düşman mülkünü yok etmek ya da zaptetmek de dahil olmak üzere geleneksel olarak sadece uluslararası silahlı çatışmalarda savaş suçu olarak tanınmış eylemler.

\subsubsection{Saldırı Suçları (Barışa Karşı Suçlar)}

Uluslararası Ceza Mahkemesi'nin yargılama yetkisi içerisine giren ve uluslararası toplumun tümünü ilgilendiren en ağır nitelikteki suçlardan sonuncusu ise saldırı suçlarıdır. Saldırı suçu, bir ülkenin sınır bütünlügüne ve siyasi bağımsızlığına diğer bir ülkenin silahlı müdahalesi olarak tanımlanmaktadır.

Saldırı suçunun Mahkeme'nin yargı yetkisine giren diğer suçlardan yani soykırım, insanlığa karşı işlenen suçlar ve savaş suçlarından önemli bir farklılığı bulunmaktadır. Bu üç tür suç üzerinde Mahkeme'nin yargılama yetkisi Statü'nün yürürlüğe girmesi ile başlarken, saldırı suçu üzerindeki yargılama yetkisini kullanabilmesi sonraki bir zamana bırakılmıştır (Aksar, 2005a: 51). Ne var ki devletler, gerek Roma Statüsü hazırlık görüşmeleri sırasında, gerek Roma Statüsü imzalandıktan sonra bu suçun tanımı konusunda uzlaşamadıklarından, saldırı suçuna ilişkin maddenin yalnızca başlığ 1 yazılabilmiş, içeriğinin ise mahkemenin kuruluşundan sekiz yıl sonra düzenlenecek gözden geçirme konferansı sırasında 
belirlenmesine karar verilmiştir. Roma Konferans1 sırasında belli bir tanımda uzlaşılamamasının nedeni, devletlerin çıkar çatışmalarından kaynaklanmaktadır. Konferans sırasında devletler, uzlaştıkları bütünün büyük parçasının uzlaşılamayan küçük parça yüzünden heba olmaması adına saldırı suçunun içeriğinin belirlenmesini ertelemişlerdir. Böyle bir düzenlemenin yapılmış olması, uluslararası toplumun saldırı suçunun tanımı ve unsurları ve aynı zamanda hangi tür eylemlerin bu kapsama dahil edileceği konusunda tam bir uzlaşmaya varamadığını da açıkça göstermektedir (Aksar, 2005a: 45).

Saldırı suçunun unsurlarının belirlenmesi konusundaki 30 Mayıs-11 Haziran 2010 tarihleri arasında Uganda'da düzenlenen Uluslararası Ceza Mahkemesi Gözden Geçirme Konferansı'nda ortak bir tanıma ulaşılmıştır. Buna göre saldırı suçu, bir devletin siyasi veya askeri eylemlerini etkili biçimde kontrol edebilme veya yönetebilme konumunda bulunan bir kimse tarafından, karakteri, ağırlığı ve boyutu itibariyle Birleşmiş Milletler Şartı'nı açıkça ihlal eden bir saldırı fiilinin planlanması, hazırlanması, başlatılması veya icrasını ifade etmektedir. Fakat, taraf devletler, aldıkları bir başka karar ile saldırı suçu konusunda Mahkeme'nin yargılama yetkisini 2017 yılı sonrasına ötelemiştir. Bu durumun ana nedeni, bu suç ile sorunu olan devletlere zaman kazandırmak, 2017 yılına kadar bu suç ile sorunu olan devletlere sorunlarını çözmeleri için firsat yaratmaktır.

\subsection{Yer Bakımından Yargı Yetkisi}

Ceza mahkemelerinin belirli bir bölgede işlenen suçlar hususunda veya failin ya da mağdurun yahut da diğer bir unsurun bulunduğu mahal (ikametgah, yakalanma, tescil makamı veya usule ilişsin işlemin yapıldığı yer vb.) esas alınarak tespit edilen yarg1 yetkisine yer bakımından yargı yetkisi denilmektedir (Çınar, 2004: 49).

Uluslararası Ceza Mahkeme'sinin yer bakımından yetkisine ilişkin Roma Statüsü'nde açık bir hüküm bulunmamaktadır. Yugoslavya ve Ruanda için oluşturulan ad hoc mahkemelerin yer bakımından yetkileri, Yugoslavya ve Ruanda toprakları ile Ruanda'ya komşu devletlerin topraklarında işlenen suçlarla sınırlandırılmışken, Uluslararası Ceza Mahkemesi'nin yer bakımından yetkisi bu tür dar bir sınırlamaya konu olmamıştır. Mahkeme, her şeyden önce Statü'ye taraf devletlerin ülkesinde veya vatandaşları tarafindan işlenilen suçlarda yetki kullanabilmektedir. BM Güvenlik Konseyi tarafından Mahkeme önüne getirilecek durumlarda taraf bir devletin ülkesinde veya onun vatandaşları tarafindan işlenmiş olması önkoşulu aranmadığı için Statü'ye taraf olsun veya olmasın herhangi bir devletin ülkesinde işlenilen suçlarda yetki kullanabilecektir (Ekşi, 2004: 59).

Mahkeme'nin kimleri nerede yargılayabileceği konusunu daha açıklıkla ifade etmek gerekirse; Roma Statüsü'ne taraf olan bir devletin ülkesinde, Statü'ye taraf olan bir devletin vatandaşları tarafından Statü'de düzenlenmiş olan suçlar işlenirse Mahkeme'nin yarg1 yetkisine sahip olacağı konusunda bir şüphe bulunmamaktadır. Statü'ye taraf olan bir devletin ülkesinde, Statü'de düzenlenmiş olan suçlar yabancı uyruklu kişilerce işlenirse, Mahkeme yine yetkili olmaktadır. Bu durumda, suçları işleyen şahısların uyruğunda oldukları devletin Statü'ye taraf olup olmadığına bakılmaksızın, Mahkeme'nin bu şahıslar üzerinde yargı yetkisi bulunmaktadır. Statü'ye taraf olmayan bir devletin ülkesinde, Statü'ye taraf olan bir devletin vatandaşları tarafından Mahkeme'nin yargı yetkisine giren suçların işlenmesi durumunda da Mahkeme'nin yarg1 yetkisi doğmaktadır. Son olarak Roma Statüsü'ne taraf olmayan bir devletin ülkesinde, Statü'ye taraf olmayan devletin vatandaşları tarafindan bahse konu olan suçların işlenmesi halinde ise Mahkeme'nin yargı yetkisi bulunmamaktadır. Sadece Birleşmiş Milletler Güvenlik Konseyi'nin BM Antlaşması'nın VII. Bölümüne uygun olarak alacağı karar ile konuyu Mahkeme'ye aktarması durumunda dava Mahkeme önüne gelebilmektedir (Çınar, 2004: 50). 


\subsection{Zaman Bakımından Yargı Yetkisi}

Ceza mahkemelerinin suç fiilinin işleniş zamanına göre belirlenen veya yargılama yapabilmesi için yetkili olduğu zaman dilimi esas alınarak tespit edilen yarg1 yetkisine zaman bakımından yargı yetkisi denmektedir (Çınar, 2004: 57).

Roma Statüsü'nde, Mahkemenin yargı yetkisinin başladığı tarihten itibaren işlenecek suçların yargılanabileceği belirtilmektedir. Mahkemenin yargılama yetkisi 1 Temmuz 2002 tarihinde başlamıştır, bu tarihten sonra işlenen suçlar Mahkeme tarafından yargılanabilir, bu tarihten önce işlenen suçlar Mahkeme tarafindan yargılanamaz.

Uluslararası Ceza Mahkemesi'nin yargı yetkisi, ceza hukukunun "suç ve ceza yaratan kuralların geçmişe yürütülmemesi" ve "yasallık" ilkelerini esas alarak sadece geleceğe yöneliktir. Roma Statüsü 11. maddeye göre, Mahkeme, Statü'ün yürürlüğe girmesinden sonra işlenmiş olan suçlar üzerinde yarg1 yetkisine sahip olacaktır. Bu hüküm, ex post facto yargılama yasağına dayanmakta ve ad hoc mahkemelerin en çok eleştirilen yönlerinden birini bertaraf etmek suretiyle daimi bir mahkemenin kurulmasının temelinde yatan düşüncelerden birisini yansitmaktadır (Uzun, 2003: 38). Ancak, Mahkeme'nin yarg1 yetkisini kullanabilmesi, taraf bir devletin ülkesinde veya vatandaşları tarafından işlenmiş olması ya da taraf olmayan devletin Mahkeme'nin yargı yetkisine rıza göstermiş olması ön koşuluna bağlandığı için Mahkeme'nin zaman bakımından yetkisinin düzenlendiği madde 11'deki hükmün uygulanması her zaman garanti altında olmayacaktır (Ekşi, 2004: 59). Eğer bir devlet Mahkeme'ye sonradan üye olursa Mahkeme, o devletle ilgili kovuşturma ve yargılama yetkisine söz konusu devletin Statü'ye imza attığı tarihten sonra sahip olacaktır.

\section{Mahkeme'nin Yargı Yetkisinin İşleyişi}

Uluslararası Ceza Mahkemesi'nin yargı yetkisinin söz konusu olabilmesi için öncelikle fiilin Roma Statüsü'ne taraf olan bir devletin ülkesinde ya da böyle bir devletin vatandaş1 tarafından işlenmiş olması gerekmektedir. Ayrıca böyle bir fiil, Statü'nün yürürlüğe girmesinden sonra (zaman bakımından yetki), fiil anında 18 yaşını doldurmuş bir gerçek kişi tarafından (kişi bakımından yetki) işlenmiş ve Statü'nün 5. maddesinde düzenlenmiş (madde bakımından yetki) suçlardan birine uygun düşer nitelikte olmalıdır. Fakat bu koşulların varlığı da, Mahkeme'nin soruşturma ve kovuşturmaya geçmesine yetmemektedir. Mahkeme nezdinde yargılama yapabilmesi de, yargı yetkisine giren bir olayın Mahkeme'ye intikal etmesine bağlıdır (Önok, 2003: 200).

Mahkeme'nin yargı yetkisine giren suçlar hakkında yargılama yetkisini kullanabilmesi, diğer bir deyişle Mahkeme'ye bir davanın sunulması üç yolla gerçekleşmektedir: Birinci yol, görev alanındaki suçlardan biri veya birkaçı işlendiği hallerde, bu durumun taraf devletlerden biri tarafından savcıya bildirilmesidir. İkinci yol, yine böyle bir veya birkaç suçun işlendiği durumlarda, BM Antlaşması VII. Bölüm uyarınca hareket etmekte olan Güvenlik Konseyi'nin bu durumu savcıya bildirmesidir. Üçüncü bir yol ise, Savcı'nın kendi inisiyatifiyle yani re'sen soruşturma başlatmasıdır.

Uluslararası Ceza Mahkemesi'nin önüne gelen bir davada, uyuşmazlığa hangi maddi hukuk hükümlerini uygulayacağı, Roma Statüsü'nün 21. maddesinde düzenlenmiştir. Buna göre, Mahkeme, öncelikle Roma Statüsü'nü, Suçun Unsurları'nı ve Usul ve Delil Kuralları'nı uygulayacaktır (Uzun, 2003: 42). Mahkeme'nin uygulayacağı hukuk kurallarının ikinci sırasında, uygun düştüğü ölçüde, uygulanabilir andlaşmalar ve uluslararası silahlı çatışma hukukunun yerleşmiş ilkeleri de dahil, uluslararası hukukun ilkeleri ve kuralları yer almaktadır. Üçüncü sırada ise, yukarıdaki kaynaklar bulunmadığı veya bunlarla sonuca ulaşmak mümkün olamadığı hallerde, Mahkeme'nin dünyanın hukuk sistemlerindeki ulusal kanunlarından çıkardığı hukukun genel ilkeleri yer almaktadır. Mahkeme'nin uygulayacağı 
veya yorumlayacağı hukukun uluslararası alanda kabul görmüş insan hakları kurallarına uygun olmalı ve herhangi bir ayrım gözetici temele dayanmamalıdır (Ekşi, 2004: 79). Diğer bir deyişle, Mahkeme'nin uygulayacağı hukuk kuralları; cinsiyet, yaş, rrk, renk, dil, dini inanç, siyasi görüş, milli, etnik veya sosyal köken ve doğum gibi temellere dayanan herhangi bir olumsuz ayrımı içermemektedir.

\section{Genel Değerlendirme ve Sonuç}

20. yüzyıla kadar birey uluslararası hukukta hak sahibi olarak kabul edilmemekteyken, bu yüzyılda uluslararası hukuk bireylere yönelerek onu uluslararası alanda hak ve sorumluluk sahibi yapmıştır. Diğer bir deyişle, uluslararası hukukta bireylerin yargılanabilirliğinin kabulü ancak geçtiğimiz yüzyılda gerçekleşebilmiştir. Uluslararası suçlardan dolayı bireylerin cezai sorumluluğunun olduğuna dair ilkenin uluslararası hukukta bir jus cogens norm oluşturduğu, bunun sonucunda da devletlerin, sorumluların yargilanması veya cezalandirılması konusundaki yükümlülüklerinin erga omnes nitelikte olduğu genel kabul gören bir durumdur (Aksar, 2005a: 56). Bu amaçla Uluslararası Ceza Mahkemesi'nin kurulması ve Mahkeme'nin faaliyete başlaması 21. yüzyıldaki uluslararası toplumun en büyük başarısıdır (Aksar, 2003a: 135).

Uluslararası toplum, kendisini olumsuz yönde etkileyen ve tehdit eden olayların sorumlularını cezalandırmak amacıyla geçmiş dönemlerde ad hoc mahkemeler kurmuştur. İnsanlık, huzur ve barış içinde yaşama amacının ancak hukuk yoluyla sağlanabileceğine inanmaktadır ve Uluslararası Ceza Mahkemesi'nin kurulmasına giden sürecin başlangıç noktası da hukuku egemen kılmak isteyen bu amaç olmuştur. Şimdiye kadar kurulmuş uluslararası örgüt veya yapılanmalar, hep güçlü devletlerin egemenliğinde kalarak, tarafsızlığı sağlayamamışlardır. Uluslararası Ceza Mahkemesi'nin öteki uluslararası oluşumlardan en önemli farkı, uluslararası bağımsız bir organı oluşudur.

1 Temmuz 2002 tarihinde çalışmalarına başlayan Uluslararası Ceza Mahkemesi, aslında uzun bir geçmişin önemli bir aşamasını teşkil etmektedir. Geçmiş yıllarda kurulmuş olan geçici mahkemelerin aksine, herhangi bir özel durum ile bağlantılı olmayıp ilk kez en ciddi nitelikteki suçları işleyen kişilerin sürekli bir mahkeme tarafından yargılanmaları ve cezalandırılmaları imkanının doğuşunu sağlamıştır. Mahkeme, uluslararası ceza hukuku kapsamında kurulmuş, devlet sorumluları tarafindan işlenebilecek en ağır suçlar olan soykırım, insanlığa karşı suçlar ile savaş suçlarını soruşturmak ve kovuşturmak amacıyla uluslararası toplum tarafından yaratılan daimi ve bağımsız bir yargı organıdır. Mahkeme, uluslararası toplumun bir bütün olarak yakından ilgilendiren çok ciddi suçların cezasız kalmaması ve bunların etkin bir şekilde kovuşturulmasının önemini göz önünde bulundurularak daha önce geçici benzerleri oluşturulan Mahkeme'nin doğal hakim ilkesine aykırılık teşkil etmeden ağır ve insanlık onuru ile bağdaşmayan suçların yargılanmasını amaçlamıştır.

Uluslararası Ceza Mahkemesi, çok önemli bir olguyu vurgulayıp somutlaştırmaktadır. $\mathrm{Bu}$ olgu, insan hakları ve insancil hukuk ihlallerinin cezalandırılması ve uluslararası adalet kavramının uygulamaya geçilmesi konusunda, dünyanın artık kararlılık gösteriyor olmasıdır. 17 Temmuz 1998'de Roma'da 160 kadar devletin, evrensel boyutta, soykırım, insanlığa karş1 suçlar ve savaș suçları gibi en ciddi uluslararası suçları yargılayacak daimi bir uluslararası ceza mahkemesi kurmaya karar vermeleri, uluslararası hukukun portresini değiştiren dev bir yenilik olup, ağır uluslararası suçların cezalandırılması konusunda bir kilometre taşı teşkil etmektedir. Tarihte ilk defa, insanlığa karşı suçlar, savaş suçları ve soykırım gibi haince eylemleri kovuşturmak ve cezalandırmak için uluslararası toplumun elinde daimi bir yargısal organ kurulmuştur. Öte yandan, uluslararası hukuk alanında, hukuk kişiliği haiz olan 
devletlerle, bu ehliyeti taşımayan devlet-dışı unsurları yan yana koyduğu gibi, gerçek şahısları uluslararası hukukun süjesi haline getirmektedir (Önok, 2003: 103-104).

Uluslararası Ceza Mahkemesi; soykırım suçları, insanlığa karşı işlenen suçlar ve savaş suçlarını işleyen kişileri yargılama yetkisiyle oluşturulmasına rağmen, Mahkeme Statüsü’nde birtakım eksiklikler bulunmaktadır. Mahkeme'nin Birleşmiş Milletler ile doğrudan bir ilişkisi olmamasına rağmen, Roma Statüsü çerçevesinde Güvenlik Konseyi'ne verilen yetkiler (örneğin saldırı suçu konusunda verilmesi düşünülen yetki), Mahkeme'nin karşısına olumsuz bir etken olarak çıkmaktadır. Uluslararası Ceza Mahkemesi gibi hukuksal niteliğe sahip bir organın, Güvenlik Konseyi gibi siyasi bir organla ilişkilendirilmiş olması, Mahkeme'nin zaman zaman Güvenlik Konseyi'nin siyasi nitelikteki zorlamalarına maruz kalması ihtimalini ortaya çıkarmaktadır. Öte yandan, terörizm suçunun Mahkeme'nin yarg1 yetkisine dahil edilmeyip, bir tavsiye kararına konu olması da, Roma Statüsü'nün eksik yönlerinden birini teşkil etmektedir. Bunun en büyük gerekçesini, bu suçun tanımı üzerinde henüz bir anlaşmaya varılamamış olması teşkil etmektedir.

Yine de Uluslararası Ceza Mahkemesi'nin kuruluşu, hukukun üstünlüğü ve evrensel insan haklarının gelişimi yönünde atılmış dev bir adım ve gelecek nesillere bir ümit kaynağı olarak değerlendirilmektedir. 30 Temmuz 2014 tarihi itibariyle Uluslararası Ceza Mahkemesi Statüsü'ne 139 devletin imza koyması ve 122 devletin taraf olması, Yeni Dünya Düzeni'nin dünyanın geriye kalan tek süper gücünün kontrolü altında olmayacağı, uluslararası toplumu evrensel bir adalet anlayışına ulaştırmanın tek yolunun hukukun üstünlüğü olduğunu göstermesi açısından da kayda değer bir gelişmedir (Aksar, 2005a: 14).

Uluslararası Ceza Mahkemesi Roma Statüsü, herhangi bir suçlamanın belirlenmesinde ve soykırım, insanlığa karşı suçlar ve savaş suçlarını işlemekle itham edilen kişilerin kamuya açık ve adil bir duruşma tarafsızca yargılanmasında uluslararası standartlarda adil yargılanma hakkının temel garantilerini içermektedir. Şu anda bu gibi suçların cezasız kalmaması ve takibi konusunda dünya üzerindeki tek ceza hukuku aygıtı Uluslararası Ceza Mahkemesi'dir. Her ne kadar zayıflıkları bulunsa bile, desteklenmemesi ve zayıf bırakılması durumunda dünya, aksi duruma oranla çok daha güvensiz bir yere dönüşecektir.

\section{Kaynakça}

Aksar, Yusuf, (2007). Evrensel Yargı Kuruluşları, Seçkin Yayınevi, Ankara.

Aksar, Yusuf, (2003a). "Uluslararası Ceza Mahkemesi ve Amerika Birleşik Devletleri", Ankara Üniversitesi Hukuk Fakültesi Dergisi, C. 52, Say1: 2.

Aksar, Yusuf, (2003b). Uluslararası Ceza Mahkemesi ve Uluslararası Ceza Usul Hukuku, Seçkin Yayınevi, Ankara.

Aksar, Yusuf, (2004). Implementing International Humanitarian Law: From the Ad Hoc Tribunals to a Permanent International Criminal Court, London, New York: Routledge.

Aksar, Yusuf, (2005a). "Uluslararası Ceza Mahkemesi ve Uygulamalarına Genel Bir Bakış", Uluslararası Hukuk ve Politika Dergisi, C. 1, No: 3, Ankara.

Aksar, Yusuf, (2005b). "Uluslararası Suçlar, Uluslararası Ceza Mahkemesi ve Yeni Türk Ceza Kanunu”, Uluslararası Hukuk ve Politika Dergisi, C. 1, No: 1, Ankara.

Amnesty International: www.amnesty.org

Aslan, Muzaffer Yasin, (2006). Teoride ve Uygulamada Savaş Suçları, Bilge Yayınevi, Ankara. 
Azarkan, Ezeli, (2003). Nuremberg'ten La Haye'ye Uluslararası Ceza Mahkemeleri, Beta Yayınevi, Kırklareli.

Başak, Cengiz, (2003). Uluslararası Ceza Mahkemeleri ve Uluslararası Suçlar, 1.Bası, Turhan Kitabevi, Ankara.

Bouchet-Saulnier, Françoise, (2002). İnsancıl Hukuk Sözlüğü, Çev. Selahattin Bağdatlı, 1. Baskı, İletişim Yayınları, İstanbul.

Çınar, Fatih, (2004). Uluslararası Ceza Mahkemelerinin Gelişimi Işı̆̆ında Uluslararası Ceza Divanı, Kazancı Hukuk Yayınevi, İstanbul.

Dağ, Ahmet Emin, (2004). Uluslararası İlişkiler ve Diplomasi Sözlüğü, Anka Yayınları, İstanbul.

Ekşi, Canan, Ateş, (2004). Uluslararası Ceza Mahkemesinin İnsanlığa Karşı Suçlar Üzerindeki Yargı Yetkisi, Seçkin Yayınevi, Ankara.

Halatçı, Ülkü, (2005). “Uluslararası Ceza Mahkemesi’nin Yargı Yetkisini Kullanabilmesinin Ön Koşulları”, Uluslararası Hukuk ve Politika Dergisi, C. 1, No: 3, Ankara.

Köprülü, Timuçin, (2005). "Uluslararası Ceza Mahkemesi Statüsünde Uluslararası İşbirliği ve Adli Yardımlaşma", Uluslararası Hukuk ve Politika Dergisi, C. 1, No: 3, Ankara.

Kurşun, Günal, (2011). 101 Soruda Uluslararası Ceza Mahkemesi, İnsan Hakları Gündemi Derneği, Ankara.

Önok, Murat, (2003). Tarihi Perspektifiyle Uluslararası Ceza Divanı, Turhan Kitabevi, Ankara.

Pazarcı, Hüseyin, (2007). Uluslararası Hukuk, Gözden Geçirilmiş 5. Bası, Turhan Kitabevi, Ankara.

Prevent Genocide International, Lemkin, Raphael, Axis Rule in Occupied Europe: Laws of Occupation, Analysis of Government, Proposal for Redress, Carnegie Endowment for World Peace, Washington, 1944, http://www.preventgenocide.org/lemkin/AxisRule1944-1.htm

Schabas, William, (2000). An Introduction to the International Criminal Court, Cambridge.

Thomas, Smith, W. (2002). "Moral Hazard and Humanitarian Law: The International Criminal Court and the Limits of Legalism", International Politics, Vol. 39, s.177.

Topal, A. Hamdi, (2005). "Uluslararası Terörizm ve Uluslararası Ceza Mahkemesi", Uluslararası Hukuk ve Politika Dergisi, C. 1, No: 3, Ankara.

Uzun, Elif, (2003). "Milletlerarası Ceza Mahkemesi Düşüncesinin Tarihsel Gelişimi ve Roma Statüsü”, Anadolu Üniversitesi Hukuk Fakültesi Sosyal Bilimler Dergisi.

Yılmaz, Alia, (2001). Uluslararası Ceza Hukuku El Kitabı, 2. Bası, Beta Yayınevi, İstanbul. 